\title{
Evaluasi Media Presentasi Perancangan Interior Rumah Air Surabaya Berbasis Virtual Tour sebagai Usaha Penerapan Building Information Modelling pada Perancangan Interior
}

\author{
Okta Putra Setio Ardianto ${ }^{1}$, Thomas Ari Kristianto ${ }^{2}$, Caesario Ari Budianto ${ }^{3}$, Anggra \\ Ayu Rucitra ${ }^{4}$, Adi Wardoyo ${ }^{5}$ \\ 1,2,3,4,5 Departemen Desain Interior, Fakultas Arsitektur, Desain dan Perencanaan, Institut Teknologi Sepuluh \\ Nopember, Surabaya 60111 Indonesia \\ ${ }^{1}$ okta@interior.its.ac.id, ${ }^{2}$ thomasjawa@prodes.its.ac.id, ${ }^{3}$ caesario.budianto@interior.its.ac.id, \\ 4anggra@interior.its.ac.id, ${ }^{5}$ wardoyoadi@interior.its.ac.id
}

\begin{abstract}
ABSTRAK
Di era revolusi industri 4.0 yang terjadi saat ini, terjadi banyak perubahan yang dipicu integrasi teknologi jaringan internet di bidang industri baik yang berbasis produk maupun jasa. Pada bidang konstruksi, fenomena tersebut menghasilkan Building Information Modelling (BIM) sebagai efek yang dihasilkan integrasi dari teknologi jaringan internet dan proses konstruksi. BIM diartikan alir kerja konstruksi di mana terjadi integrasi data di antara banyak pihak dan di berbagai tahapan kerja berbasis data digital melalui jaringan internet. Saat ini BIM telah banyak diadopsi di proses kontruksi mulai tahap perencanaan, pembangunan hingga operasional terutama pada pekerjaan konstruksi yang rumit seperti bangunan sektor infrastruktur. Selain telah banyak digunakan, aplikasi BIM memiliki beberapa tingkatan dari sebagai visualisasi perencenaan, integrasi perencanaan dan waktu pelaksanaan hingga integrasi produksi komponen konstruksi serta pemeliharaannya. Di masa depan, BIM akan diperkirakan akan makin banyak diterapkan sebagai standar kerja di banyak sektor industri konstruksi seiring dengan makin matang serta pesatnya efek revolusi industri 4.0.

Studi ini menggunakan metode studi kasus media presentasi hasil perancangan interior Rumah Air Surabaya berbasis Virtual Tour. Tujuan dari studi adalah mengetahui sejauh mana teknik tersebut mengaplikasikan prinsip alir kerja BIM. Metode analisa menggunakan evaluasi heuristik untuk menganalisa sampel dengan dukungan studi literatur mengenai BIM. Hasil dari studi menunjukkan bahwa teknik Virtual Tour dapat dikategorikan sebagai penerapan alir kerja BIM tahap 3D yaitu mampu mewujudkan virtualisasi hasil perancangan interior yang interaktif. Berbeda dengan presentasi menggunakan $3 D$ render yang statis, teknik Virtual Tour memberikan kesempatan pada perancang untuk mampu membangun interaksi dan pemahaman yang lebih pada klien sehingga dapat mempermudah proses finalisasi desain. Terdapat kekurangan yaitu terbatasnya interaksi karena Virtual Tour memiliki titik-titik lokasi dan kemampuan kendali interaktif yang terbatas. Disarankan, untuk selanjutnya kekurangan tersebut dapat diatasi dengan teknik 3D render menggunakan teknik realtime rendering menggunakan game engine.
\end{abstract}

Kata kunci: interior; $3 D$ render; panorama; interaktif; BIM

\section{ABSTRACT}

In this era of industrial revolution 4.0, there were many changes triggered by the integration of internet network technology in the field of industry both based on products and services. In the construction sector, this phenomenon resulted in Building Information Modeling (BIM) as an effect resulting from the integration of internet network technology and the construction process. BIM is defined as the flow of construction work in which data integration occurs between many parties and at various stages of work based on digital data through the internet network. Currently BIM has been widely adopted in the construction process from the planning, development to operational phases, especially in complex construction works such as infrastructure sector buildings. In addition to widely used, BIM 
Okta P. S. Ardianto, Thomas A. Kristianto, Caesario A. Budianto, Anggra A. Rucitra, Adi Wardoyo Evaluasi Media Presentasi Perancangan Interior Rumah Air Surabaya Berbasis Virtual Tour sebagai Usaha Penerapan Building Information Modelling pada Perancangan Interior

application has several levels, namely as planning visualization, integration planning and implementation period as well as the integration of component production of construction and maintenance. In the future, BIM will be expected to be more widely applied as a work standard in many sectors of the construction industry along with more mature and the rapid effects of the 4.0 industrial revolution.

This study uses a case study method that presents the results of the interior design of Rumah Air Surabaya based on the Virtual Tour. The purpose of the study is to determine the extent to which the technique applies the flow principle of BIM work. The method of analysis uses heuristic evaluation to analyze samples with the support of literature studies on BIM. The results of the study show that the $3 D$ panorama rendering technique can be categorized as the application of the $3 D$ phase of BIM work, which is able to realize the virtualization of the results of interactive interior design. In contrast to presentations using static $3 D$ rendering, $3 D$ panorama rendering techniques provide an opportunity for designers to be able to build more interaction and understanding with clients so as to facilitate the process of finalizing the design. There are shortcomings, namely limited interaction because 3D panorama rendering has limited location points and interactive control capabilities. Further recommendation, these deficiencies can be overcome by the $3 D$ rendering technique using realtime rendering techniques using the game engine.

Keyword: interior; 3D rendering; panorama; interactive; BIM

\section{PENDAHULUAN}

\section{A. Latar Belakang}

Dalam beberapa tahun terakhir, gagasan mengenai Industri 4.0 semakin lama semakin menguat untuk diimplementasikan ke berbagai bidang. Secara umum kita semua mengenal bahwa hingga saat ini telah terjadi empat kali revolusi industri menurut European Parliamentary Research Service (Davies, 2015). Revolusi industri yang pertama terjadi saat penemuan mesin uap dan mekanisasi di Inggris pada tahun 1784. Revolusi yang kedua terjadi sekitar akhir abad ke-19 ketika mesin produksi bertenaga listrik digunakan untuk kegiatan produksi secara masal. Komputerisasi untuk proses otomasi produksi produk secara masal mulai digunakan tahun 1970 yang menandai revolusi industri ketiga. Perkembangan yang pesat dari teknologi sensor, jaringan data melalui internet, dan analisis data memunculkan gagasan untuk mengintegrasikan seluruh teknologi tersebut ke dalam berbagai bidang industri yang menjadi dasar dari gagasan revolusi industri ke empat yang lebih dikenal sebagai Industri 4.0.

Riset mengenai Industri 4.0 mengalami tren kenaikan yang signifikan. Hasil tersebut menunjukkan bahwa posisi riset Industri 4.0 saat ini berada pada tahap pematangan konsep yang bertujuan agar konsep Industri 4.0 dapat diterapkan secara global tidak hanya di negara maju namun juga negara-negara berkembang (Prasetyo \& Sutopo, 2018). Tren riset mengenai Industri 4.0 secara berturut-turut didominasi oleh riset bidang manufaktur, proses bisnis, edukasi, teknologi informasi, manajemen dan lainnya (pelayanan publik, pertanian, industri makanan, otomotif, hukum, sosial ekonomi, konstruksi dan kelistrikan). Oleh sebab itu dapat diambil kesimpulan awal bahwa ketertarikan peneliti untuk meriset mengenai Industri 4.0 di bidang konstruksi termasuk masih minim. Fenomena tersebut juga dapat menjadi tanda bahwa perhatian terhadap transformasi industri bidang konstruksi pada Industri 4.0 masih kecil sehingga penelitian bidang konstruksi, lebih khusus keilmuan desain interior mendesak untuk dilakukan dikarenakan sifat kebaruannya dan kebutuhan untuk merespon tantangan di masa depan terkait fenomena Industri 4.0.

Manfaat terbesar gagasan Industri 4.0 melalui implementasi digitalisasi dan virtualisasi pada bidang konstruksi adalah pengintegrasian proses manajemen konstruksi yang panjang dan 
bervariasi sehingga mempermudah proses koordinasi banyak pihak terakait sehingga mencapai hasil konstruksi yang maksimal. Building Information Modelling (BIM) menjadi central technologies untuk memberikan manfaat yang telah disebut sebelumnya (Oesterreich \& Teuteberg, 2016). Pada tahapan praktek BIM beberapa kali telah digunakan pada proses konstruksi infrastruktur dan arsitektur namun belum banyak yang menggunakannya pada konstruksi ruang interior. Namun pada tahapan riset beberapa penelitian yang pernah menstudi mengenai penerapan BIM pada konstruksi interior, salah satunya adalah mengenai metode pengawasan capaian pekerjaan konstruksi menggunakan 3D Walk-through Model yang mempermudah proses pemahaman pihak pengawas dalam memantau capaian proses konstruksi secara lebih presisi (Roh, Aziz, \& Peña-Mora, 2011).

Studi ini menggunakan metode studi kasus dengan sampel beberapa presentasi hasil perancangan interior berbasis Virtual Tour yang telah ada sebagai bagian dari output yang mempraktikkan teknologi BIM 3D. Tujuan dari studi adalah mengetahui sejauh mana teknik tersebut mengaplikasikan prinsip alir kerja BIM pada tahap perancangan interior. Hal tersebut diharapkan dapat memberikan penjelasan mengenai seberapa efektif presentasi hasil perancangan interior berbasis Virtual Tour dalam mendukung proses komunikasi desain antara perancang dan klien yang sejalan dengan gagasan Industri 4.0.

\section{B. Tujuan dan Batasan Pembahasan}

Dengan memperhatikan latar belakang yang telah dijelaskan pada bagian sebelumnya, tujuan dari studi ini adalah:

- Mengevaluasi dan menjelaskan teknik presentasi hasil perancangan interior berbasis Virtual Tour terkait korelasinya penerapan alir kerja BIM pada tahap perancangan interior.

- Menjadikan hasil studi ini sebagai masukan pengembangan teknik presentasi hasil perancangan interior berbasis Virtual Tour dalam mendukung bidang keilmuan desain interior dalam menyambut era Industri 4.0.

Untuk mencapai tujuan tersebut diberikan batasan bahwa sampel media presentasi hasil perancangan interior berbasis Virtual Tour yang dijadikan studi adalah yang telah selesai dibuat dan dipresentasikan ke khalayak umum serta hasil karya tim yang tergabung pada laboratorium Sains dan Teknologi Interior Departemen Desain Interior ITS. Hal ini dimaksudkan agar mempermudah kelangsungan studi karena terbantu pada ketersediaan bahan studi yang cukup. Media presentasi hasil perancangan interior berbasis Virtual Tour terpilih yaitu perancangan interior Rumah Air PDAM Surya Sembada Surabaya dan Zenna Hotel Surabaya.

\section{Dasar Teori}

\section{Teknologi Industri 4.0 dan Dunia Konstruksi}

\section{Keuntungan dan Tantangan Teknologi Industri 4.0}

Gagasan Industri 4.0 pada umumnya menggabungkan otomasi produksi yang telah diimplementasikan pada revolusi industri ketiga dengan teknologi digitalisasi yang berbasis jaringan internet. Terkait industri konstruksi terdapat beberapa keuntungan dan tantangan yang harus dihadapi seluruh pihak (Tabel 1). Dari keuntungan dan tantangan tersebut disusun sebuah analis value chain dampak dari Industri 4.0 pada industri konstruksi yang dapat diperhatikan pada gambar 1. 
Okta P. S. Ardianto, Thomas A. Kristianto, Caesario A. Budianto, Anggra A. Rucitra, Adi Wardoyo Evaluasi Media Presentasi Perancangan Interior Rumah Air Surabaya Berbasis Virtual Tour sebagai Usaha Penerapan Building Information Modelling pada Perancangan Interior

Tabel 1. Keuntungan dan Tantangan Penerapan Otomasi serta Digitalisasi Industri 4.0 pada Industri Konstruksi

\begin{tabular}{|c|c|}
\hline $\begin{array}{l}\text { Keuntungan Penerapan Teknologi } 4.0 \text { di } \\
\text { Industri Konstruksi }\end{array}$ & $\begin{array}{c}\text { Tantangan Penerapan Teknologi } 4.0 \mathrm{di} \\
\text { Industri Konstruksi }\end{array}$ \\
\hline $\begin{array}{l}\text { Cost saving, penggunaan otomasi } \\
\text { memungkinkan menghemat biaya jasa } \\
\text { konstruksi, teknologi sensor yang makin } \\
\text { presisi juga dapat menghemat mengoptimasi } \\
\text { dan penggunaan bahan }\end{array}$ & $\begin{array}{l}\text { Hesitation to adopt, keraguan pihak-pihak } \\
\text { terkait karena teknologi ini masih tergolong } \\
\text { baru dan membutuhkan lebih banyak } \\
\text { investasi di awal. }\end{array}$ \\
\hline $\begin{array}{l}\text { Time savings, sistem pabrikasi baru } \\
\text { memungkinkan konsep konstruksi yang } \\
\text { lebih menghemat waktu seperti konsep } \\
\text { Prefabrication atau Additive Manufacturing }\end{array}$ & $\begin{array}{l}\text { High implementation cost, untuk inisiasi } \\
\text { awal membutuhkan ivestasi yang cukup } \\
\text { tinggi untuk pengadaan peralatan, pelatihan } \\
\text { sumber daya manusia maupun biaya jasa } \\
\text { konsultasi sistem tersebut. }\end{array}$ \\
\hline $\begin{array}{l}\text { On-time and on-budget delivery, } \\
\text { penggunaan BIM dengan dimensi } \\
\text { penjadwalan dan penyusunan anggaran } \\
\text { memungkinkan waktu proses konstruksi dan } \\
\text { biaya mampu dioptimasi. }\end{array}$ & $\begin{array}{l}\text { Organisational and process changes, bila } \\
\text { sistem baru diimplementasi maka terdapat } \\
\text { perubahan tata kelola organisasi dan proses } \\
\text { bisnis suatu bisnis kontruksi sehingga } \\
\text { diperlukan usaha transisi. }\end{array}$ \\
\hline $\begin{array}{l}\text { Improving quality, penggunaan BIM atau } \\
\text { program simulasi lainnya dapat } \\
\text { meminimalkan error pada saat perancangan. }\end{array}$ & $\begin{array}{l}\text { Need for enhanced skills, teknologi baru } \\
\text { membutuhkan kemampuan teknis pengelola } \\
\text { yang lebih sehingga diperlukan upgrade } \\
\text { sumber daya manusia untuk operasional. }\end{array}$ \\
\hline $\begin{array}{l}\text { Improving collaboration and } \\
\text { communication, penggunaan alir kerja BIM } \\
\text { dan teknologi cloud dapat memungkinkan } \\
\text { terjadinya kolaborasi tanpa hambatan jarak. }\end{array}$ & $\begin{array}{l}\text { Knowledge management, sebagai industri } \\
\text { yang melibatkan banyak pihak terkait bila } \\
\text { terdapat satu teknologi baru menuntut } \\
\text { banyak bagian mengetahui pengetahuan } \\
\text { mengenai teknologi tersebut dapat } \\
\text { mengurangai optimalisasi keseluruhan } \\
\text { proses kerjatentangnya. }\end{array}$ \\
\hline $\begin{array}{l}\text { Improving customer relationship, } \\
\text { penggunaan teknologi VR atau AR atau } \\
\text { media interaktif lain dapat memberikan } \\
\text { pengalaman berbeda dan komunikasi efektif } \\
\text { antar pihak terutama klien sehingga dapat } \\
\text { terjalin hubungan yang lebih kuat. }\end{array}$ & $\begin{array}{l}\text { Acceptance, selayaknya hal baru lainnya, } \\
\text { teknologi Industri } 4.0 \text { akan memiliki respon } \\
\text { beragam dari banyak pihak terkait. Ada } \\
\text { sebagian yang akan mengadaptasi atau } \\
\text { sebagian yang menolak. }\end{array}$ \\
\hline
\end{tabular}




\begin{tabular}{|c|c|}
\hline $\begin{array}{l}\text { Keuntungan Penerapan Teknologi } 4.0 \text { di } \\
\text { Industri Konstruksi }\end{array}$ & $\begin{array}{c}\text { Tantangan Penerapan Teknologi } 4.0 \text { di } \\
\text { Industri Konstruksi }\end{array}$ \\
\hline $\begin{array}{l}\text { Enhancing safety, isu keselamatan sangat } \\
\text { penting di bidang konstruksi terutama pada } \\
\text { tahap pelaksaanan karena kondisi proyek } \\
\text { yang belum ideal. Penggunaan teknologi } \\
\text { virtualisasi pelatihan keselamatan atau alat } \\
\text { perlindungan diri yang smart dapat } \\
\text { mengotimalkan keselamatan. }\end{array}$ & $\begin{array}{l}\text { Lack of standards and reference } \\
\text { architectures, dikarenakan Industri } 4.0 \\
\text { adalah sistem baru dengan tingkat } \\
\text { kematangan yang berbeda dari masing- } \\
\text { masing komponennya sehingga belum ada } \\
\text { standar-standar acuan terutama yang } \\
\text { berhubungan dengan industri konstruksi. }\end{array}$ \\
\hline $\begin{array}{l}\text { Improving the image of the industry, } \\
\text { penggunaan tranformasi digital pada industri } \\
\text { konstruksi membuat atau bahkan memaksa } \\
\text { seleksi ketat pihak-pihak yang terlibat untuk } \\
\text { mahir dalam hal teknologi sehingga } \\
\text { mengubah citra dari pihak-pihak tersebut } \\
\text { menjadi lebih modern dan siap dalam } \\
\text { menyambut tantangan masa depan. }\end{array}$ & $\begin{array}{l}\text { Higher requirements for computing } \\
\text { equipment, gagasan Industri } 4.0 \text { yang } \\
\text { banyak menggunakan peralatan komputasi } \\
\text { dengan spesifikasi tinggi sehingga } \\
\text { memerlukan penyediaan peralatan baru. }\end{array}$ \\
\hline \multirow[t]{3}{*}{$\begin{array}{l}\text { Improving sustainability, penggunaan data } \\
\text { analisis, teknologi sensor dan perancangan } \\
\text { berbasis pada simulasi performa bangunan } \\
\text { (terintegrasi dalam BIM) dapat } \\
\text { mengusahakan proses konstruksi lebih tidak } \\
\text { merusak lingkungan. }\end{array}$} & $\begin{array}{l}\text { Data security and data protection, adanya } \\
\text { proses digitalisasi seluruh data-data terkait } \\
\text { pekerjaan diperlukan keamanaan data. } \\
\text { Selain itu, adanya kebutuhan sharing dan } \\
\text { kolaborasi melalui internet kebanyakan data } \\
\text { termasuk yang sangat penting juga akan } \\
\text { melalui proses sharing sehingga keamanan } \\
\text { jaringan internet menjadi isu yang juga } \\
\text { mengemuka. }\end{array}$ \\
\hline & $\begin{array}{l}\text { Enhancement of existing communication } \\
\text { networks, selain isu keamanan terdapat isu } \\
\text { kehandalan jaringan internet dikarenakan } \\
\text { banyak pengaplikasian kolaborasi } \\
\text { menggunakan teknologi jaringan internet. }\end{array}$ \\
\hline & $\begin{array}{l}\text { Regulatory compliance,penggunaan } \\
\text { teknologi sensor yang memdapatkan data } \\
\text { memunculkan isu kontradiksi dengan } \\
\text { peraturan tertentu seperti etika dan peraturan } \\
\text { milik perusahaan masing-masing pihak } \\
\text { terakait. }\end{array}$ \\
\hline
\end{tabular}


Okta P. S. Ardianto, Thomas A. Kristianto, Caesario A. Budianto, Anggra A. Rucitra, Adi Wardoyo Evaluasi Media Presentasi Perancangan Interior Rumah Air Surabaya Berbasis Virtual Tour sebagai Usaha Penerapan Building Information Modelling pada Perancangan Interior

\begin{tabular}{|c|l|}
\hline $\begin{array}{c}\text { Keuntungan Penerapan Teknologi 4.0 di } \\
\text { Industri Konstruksi }\end{array}$ & $\begin{array}{c}\text { Tantangan Penerapan Teknologi 4.0 di } \\
\text { Industri Konstruksi }\end{array}$ \\
\hline & $\begin{array}{l}\text { Legal and contractual uncertainty, belum } \\
\text { adanya regulasi yang mengatur mengenai } \\
\text { sistem tertentu semisal kontraktual dan } \\
\text { tender dengan sistem BIM sehingga belum } \\
\text { ada acuan pelaksanaan yang mengatur. }\end{array}$ \\
\hline
\end{tabular}

Sumber: Oesterreich \& Teuteberg (2016)

\section{Integrasi Teknologi Industri 4.0 dalam Bidang Konstruksi}

Pada bagian sebelumnya telah dijelaskan beberapa keuntungan dan tantangan penerapan gagasan Industri 4.0 pada industri bidang konstruksi. Dari hal tersebut Oesterreich (2016) mengusulkan integrasi Industri 4.0 pada industri bidang konstruksi melalui analisa value chain industri konstruksi yang dapat diperhatikan pada gambar 1. Integrasi tersebut memperhatikan adanya karakteristik spesifik industri konstruksi serta sifat dari suatu pekerjaan konstruksi yang kompleks dan keikutsertaan banyak pihak terkait di dalamnya. Secara umum terdapat tiga dimensi integrasi dengan penjelasan inti sebagai berikut:

- Integrasi horizontal yaitu Industri 4.0 dapat membantu integrasi banyak pihak terkait dalam jaringan nilai/value sebagai hasil dari meningkatnya jumlah pihak terkait yang terlibaty dalam proyek (kontraktor, pelanggan, arsitek, perancang, subkontraktor, pemasok). Contoh kasus, dalam proyek konstruksi skala besar, kemungkinan terdapat ratusan peserta proyek yang berbeda ikut terlibat. Dengan demikian, penggunaan teknologi Industri 4.0 dalam dimensi 2 dan 3 dapat membantu menciptakan lingkungan konstruksi yang cocok untuk meningkatkan kolaborasi dan komunikasi, misalnya melalui penggunaan sistem kerja kolaborasi berbasis teknologi cloud terpusat dipadu dengan alir kerja penggunaan Building Information Modeling, Mobile Computing dan Augmented Reality.

- Integrasi digital end-to-end pada seluruh rantai nilai/value yaitu penggunaan teknologi yang melibatkan semua pihak terkait dalam suatu proyek pada semua tahap proyek konstruksi secara menyeluruh (Tendering, briefing, design, plan, construct and use \& maintain)., misalnya penggunaan Building Information Modelling, Cyber-Physical Systems and Mobile Computing untuk menyampaikan pendekatan teknik digital terintegrasi.

- Integrasi vertikal pada sistem manufaktur yang menggunakan integrasi sistem IT, misalnya digunakannya proses manufaktur sebuah part konstruksi berprinsip otomasi dengan $\mathrm{p}$ penggunaan teknologi digitalisasi dan virtualisasi sehingga memperkecil kemungkinan cacat produksi karena tidak optimalnya pihak terkait dalam proses manufaktur (Marketing, $R$ and D, Planning, Production and Logistic, IT and Shared Service, HRD dan Finance). Secara keseluruhan, Industri 4.0 dapat membantu perusahaan konstruksi untuk mengurangi kompleksitas dan ketidakpastian, untuk meningkatkan pertukaran informasi dan komunikasi antara para pihak terkait proyek sehingga dapat meningkatkan produktivitas dan kualitas. 


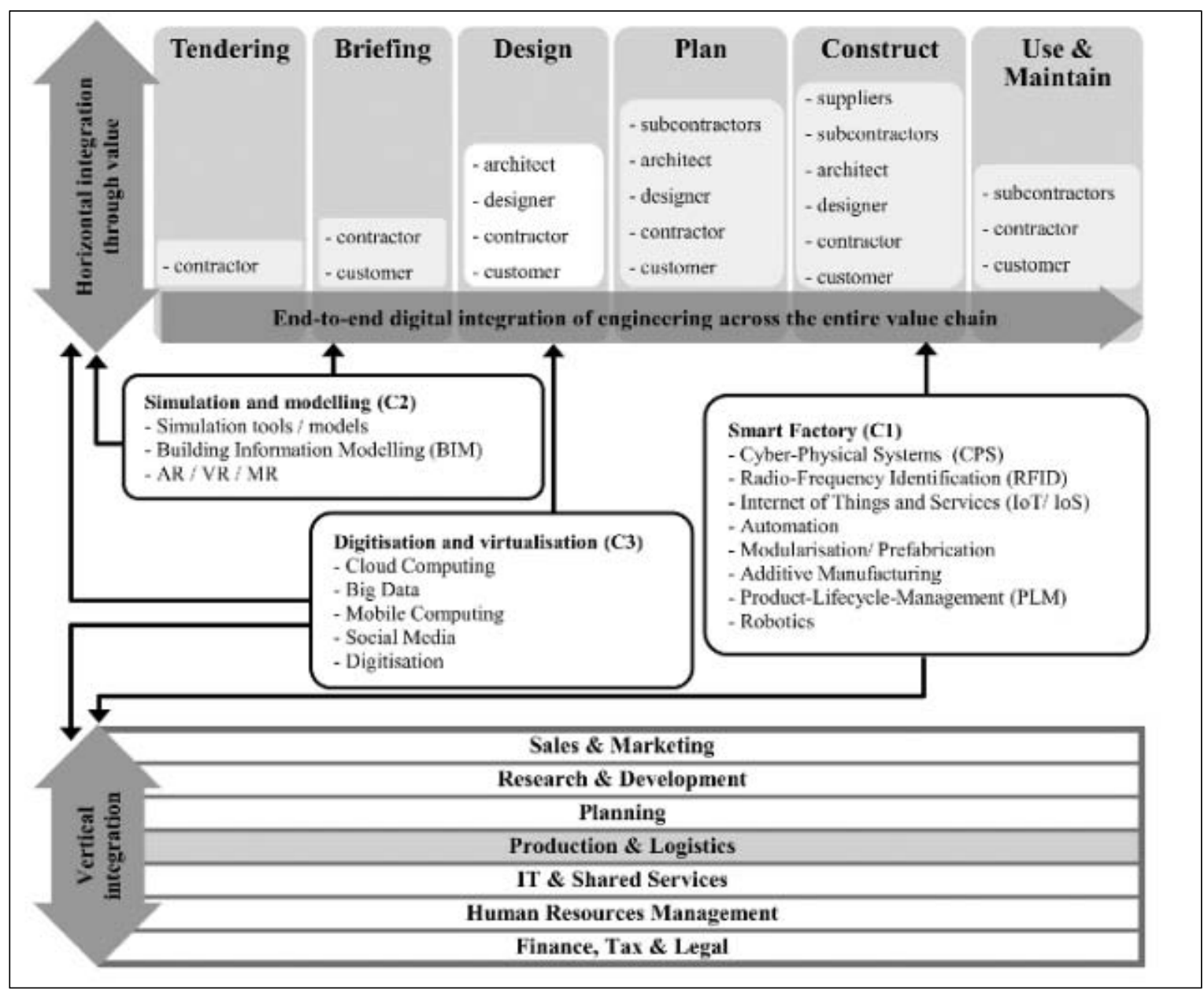

Gambar 1. Bagan Dampak Penerapan Industri 4.0 pada Value Chain Industri Konstruksi. Sumber: Oesterreich \& Teuteberg (2016)

\section{Building Information Modelling (BIM) dan Industri Konstruksi Indonesia}

\section{Pengertian dan Dimensi BIM}

Building Information Modelling (BIM) adalah alir kerja yang secara signifikan menjadi populer pada industri konstruksi seiring dengan menguatnya gagasan Industri 4.0. Definisi BIM adalah alir kerja konstruksi menggunakan pemodelan 3D suatu bangunan menggunakan komputer yang terintegrasi dengan serangkaian proses terkait dengannya untuk menghasilkan, mengkomunikasikan, dan menganalisa model bangunan yang digunakan pada seluruh proses kontruksi (perencanaan, pembangunan hingga operasional) dan dioperasikan seluruh pihak yag terlibat dalam proses kontruksi tersebut (Eastman, Teicholz, Sacks, \& Liston, 2008). Model bangunan yang menggunakan prinsip BIM memiliki karakteristik:

- Setiap komponen di dalamnya bersifat 'cerdas' yaitu dapat dikenali dengan jelas secara visual, mengandung atribut data yang mengandung informasi terkait bangunan dan bersifat parametrik.

- Atribut data terkait bangunan bersifat memudahkan kerja kolaborasi para pihak terkait seperti jadwal pelaksanaan, spesifikasi bahan, analisa konsumsi energi dan lain sebagainya. 
Okta P. S. Ardianto, Thomas A. Kristianto, Caesario A. Budianto, Anggra A. Rucitra, Adi Wardoyo Evaluasi Media Presentasi Perancangan Interior Rumah Air Surabaya Berbasis Virtual Tour sebagai Usaha Penerapan Building Information Modelling pada Perancangan Interior

- Data tersebut bersifat konsisten dan komprehensif, artinya jika ada perubahan data oleh salah satu pihak di salah satu proses kontruksi maka akan terjadi perubahan secara real time di data yang ada di pihak yang lain.

- Data tersebut bersifat kompleks namun dapat terkoordinasi dengan baik dan divisualkan dengan menarik sehingga mudah dipahami.

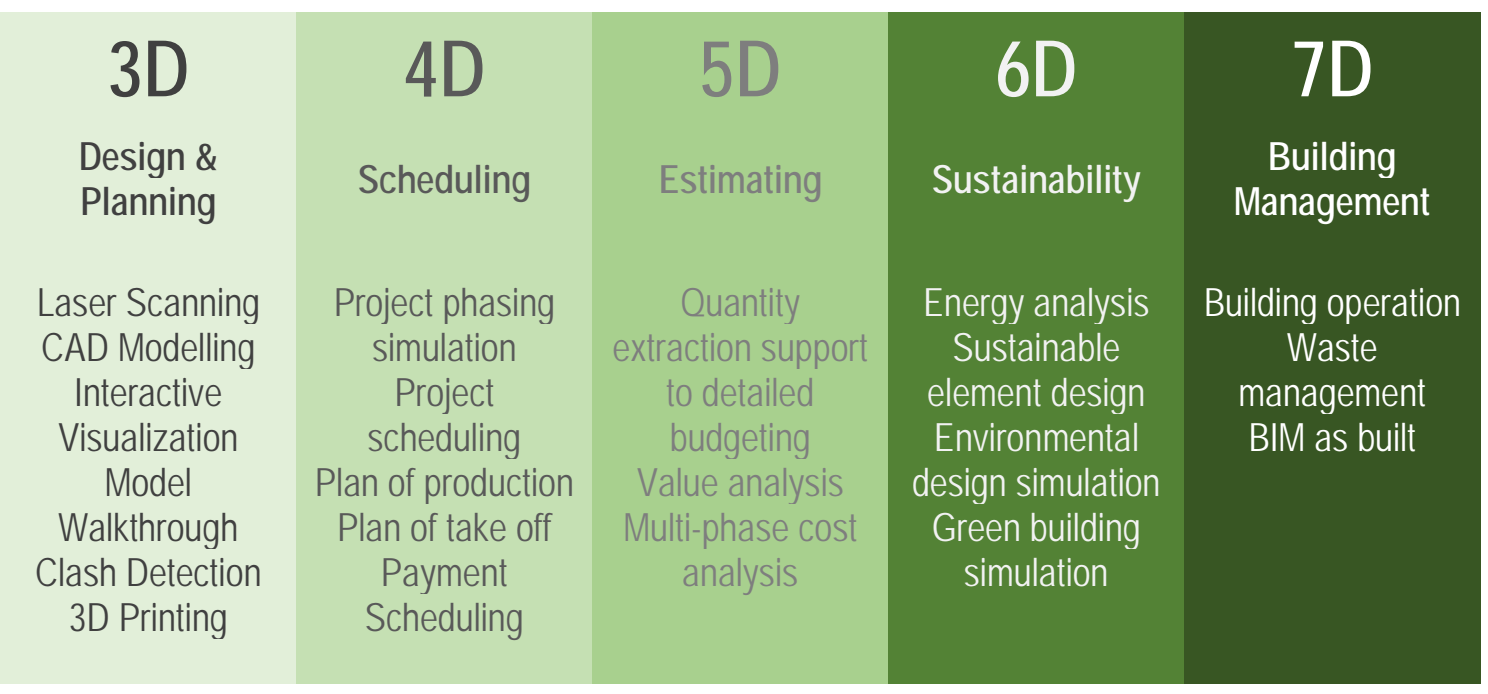

Gambar 2. Bagan Dimensi Building Information Modelling (BIM)

Sumber: Dokumentasi Penulis (2019)

Sebagai suatu alir kerja, BIM memiliki tahapan (dimensi) yang merepresentasikan tingkat implementasi / maturity terhadap proses konstruksi. Secara umum terdapat 5 dimensi (Gambar 2) dengan penjelasan sebagai berikut:

- 3D / Parametric Data for Collaborative Work, BIM 3D membantu pihak terkait projek untuk mengelola kolaborasi multidisiplin secara lebih efektif dalam memodelkan dan menganalisis masalah spasial dan struktural yang kompleks. Manfaat dominannya adalah peningkatan visualisasi dan komunikasi maksud desain, eningkatan kolaborasi multidisiplin dan mengurangi pengerjaan ulang karena kesalahaan komunikasi pada tahap desain.

- 4D / Scheduling, BIM 4D memungkinkan peserta untuk mengekstraksi dan memvisualisasikan progress kegiatan selama masa proyek sehingga dari pembuatan hingga pengawasan jadwal pekerjaan menjadi lebih optimal.

- 5D / Estimating, BIM 5D digunakan untuk pelacakan anggaran dan kegiatan biaya terkait projek. 5D dilakukan bersamaan dengan 3D dan 4D (Waktu) memungkinkan pihak terakait projek untuk memvisualisasikan data kemajuan kegiatan mereka dan biaya dari waktu ke waktu.

- 6D / Sustainabilty, BIM 6D mengintegrasikan perancangan dengan analisis performa bangunan yang fokus pada keberlanjutan dan konsep ramah lingkungan.

- $\quad$ 7D / Building Management, BIM 7D memungkinkan pihak terakit manajemen bangunan untuk mengetahui dan melacak data aset yang relevan seperti status komponen, spesifikasi, manual pemeliharaan / operasi, data garansi dan lain sebagainya dengan lebih detail serta relevan terhadap kondisi bangunan. 


\section{Roadmap BIM di Indonesia}

Indonesia menduduki peringkat pasar konstruksi terbesar di Asia Tenggara dan nomor 4 di Asia, sektor konstruksi ini menyumbang 10 \% dari Gross Domestic Product (GDP) nasional (Kementrian Pekerjaan Umum dan Perumahan Rakyat, 2018). Dengan fakta tersebut Kementerian Pekerjaan Umum dan Perumahan Rakyat Indonesia mencanangkan roadmap implementasi BIM di Indonesia sebagai acuan tata kelola alir kerja tersebut pada projek konstruksi di Indonesia. Jangka waktu roadmap tersebut adalah tahun 2017 hingga 2024 meliputi beberapa bagian implementasi yang dapat diperhatikan pada tabel 2. Tujuan dari pencanangan tersebut adalah:

- Peningkatan Produktivitas dan efisiensi proses konstruksi.

- Kolaborasi semua stakeholder konstruksi (Investor, perencana, kontraktor dan manufaktur).

- Peningkatan mutu, pengendalian biaya dan manajemen waktu dari proyek-proyek konstruksi Indonesia.

- Regulator secara aktif memberikan approval, memonitor dan supervisi progres pekerjaan konstruksi secara digital sebagaimana negara maju lainnya.

Tabel 2. Roadmap BIM Indonesia 2017-2024

\begin{tabular}{|c|c|c|c|}
\hline FASE ADOPSI & FASE DIGITALISASI & FASE KOLABORASI & FASE INTEGRASI \\
\hline $\begin{array}{c}\text { Stakeholder } \\
\text { konstruksi } \\
\text { mengadopsi BIM } \\
\text { Penyusunan } \\
\text { standard BIM } \\
\text { Nasional (SNI) } \\
\text { Standar kurikulum } \\
\text { dan kompetensi } \\
\text { BIM untuk } \\
\text { universitas dan } \\
\text { profesi }\end{array}$ & $\begin{array}{c}\text { Perizinan } \\
\text { (e-submission) } \\
\text { Monitoring dan } \\
\text { supervisi dengan } \\
\text { teknologi digital } \\
\text { Dimulainya pasar } \\
\text { digital untuk } \\
\text { sektor konstruksi } \\
\text { (penguatan } \\
\text { database) }\end{array}$ & $\begin{array}{c}\text { Standar terkait } \\
\text { kolaborasi } \\
\text { industri } \\
\text { konstruksi } \\
\text { Implementasi } \\
\text { Virtual Design } \\
\text { dan Lean } \\
\text { Contruction (VDC) } \\
\text { Implementasi } \\
\text { BIM (3D s/d 7D) }\end{array}$ & $\begin{array}{c}\text { Implementasi } \\
\text { cloud } \\
\text { construction } \\
\text { management } \\
\text { Integrasi sistem } \\
\text { proses } \\
\text { konstruksi } \\
\text { (perizinan, claim, } \\
\text { commisioning, } \\
\text { handover, dll) }\end{array}$ \\
\hline
\end{tabular}

Sumber: Kementerian Pekerjaan Umum dan Perumahan Rakyat (2018)

\section{Presentasi Perancangan Interior Berbasis Virtual Tour.}

\section{Pengertian dan Teknis Pembuatan}

Virtual Reality (VR) adalah media yang menggambarkan lingkungan secara virtual serta memiliki fitur multi sensor, bersifat imersif dan interaktif yang akan banyak digunakan manusia modern dalam kegiatan bekerja, belajar dan hiburan (Roussou, 2004). Istilah Virtual Tour adalah istilah yang memiliki pengertian yang cenderung sama dengan VR di mana pengguna dapat memahami dan berorientasi dalam lingkungan buatan dan dapat bernavigasi sebagai fitur interaktifnya. Penyebutan Virtual Tour sebagai varian dari VR banyak digunakan pada media untuk aktivitas wisata dan edukasi secara daring sehingga lazim menggunakan istilah tour atau wisata. Namun VR dan Virtual Tour dapat sama-sama menyajikan secara interaktif suatu tampilan rekaan dunia nyata (artifisial) yang memberikan efek seakan-akan penikmatnya 
Okta P. S. Ardianto, Thomas A. Kristianto, Caesario A. Budianto, Anggra A. Rucitra, Adi Wardoyo Evaluasi Media Presentasi Perancangan Interior Rumah Air Surabaya Berbasis Virtual Tour sebagai Usaha Penerapan Building Information Modelling pada Perancangan Interior

berada pada satu titik lalu dapat menikmati pemandangan sekelilingnya secara utuh. Untuk dapat membuat virtual tour dapat menggunakan gambar atau video panorama dengan sudut pengambilan $360^{\circ}$ dengan format cylindrical maupun shperical. Contoh gambar $360^{\circ}$ shperical dapat diperhatikan pada gambar 3.

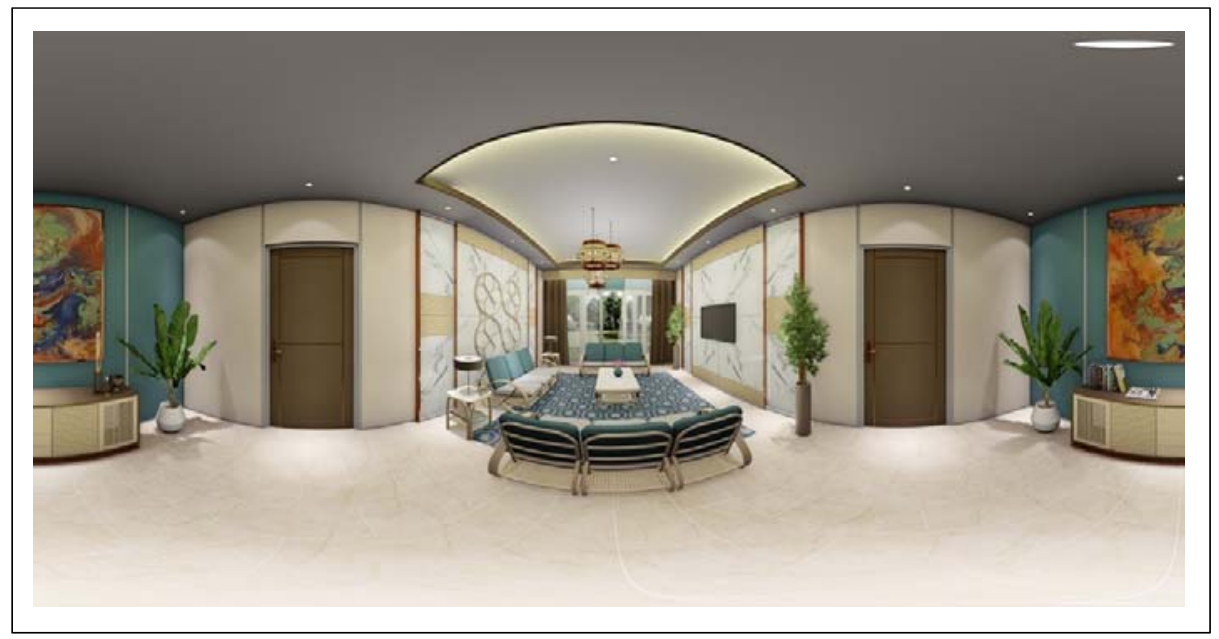

Gambar 3. Contoh Gambar $360^{\circ}$ Shperical Interior Ruangan Sumber: Dokumentasi Penulis (2019)

Pada dasarnya untuk menampilkan VR maupun Virtual Tour dibutuhkan 2 jenis perangkat keras yaitu media penampilnya (display) dan perangkat pengendali (control), perangkat yang banyak digunakan saat ini dapat diperhatikan pada gambar 4. Piranti display sebagai penampil media sedangkan piranti control sebagai implementasi konsep interaktif sehingga pengguna dapat menavigasi, berinteraksi dan mendapatkan informasi penjelas. Penggunaan Virtual Tour dimungkinkan sebagai media dalam teknik presentasi hasil perancangan interior. Hal tersebut dikarenakan makin berkembangnya perangkat lunak pemrosesan dan visualisasi 3D yang dapat menghasilkan gambar render hasil perancangan dengan format panorama. Media presentasi perancangan interior yang menjadi obyek penelitian ini adalah hasil dari implementasi teknik presentasi hasil perancangan interior berbasis Virtual Tour yang telah dilakukan penulis bersama tim pada perancangan interior Rumah Air Surabaya. Secara garis besar setelah konsep awal perancangan tersusun secara utuh selanjutnya dilakukan pemodelan 3D menggunakan komputer dilanjutkan dengan proses visualisasi yang mengasilkan gambar render panorama dan terakhir dilakukan proses konversi dari gambar panorama menjadi media berbasis Virtual Tour sebagai bahan presentasi untuk disajikan pada klien atau masyarakat umum (Gambar 5).

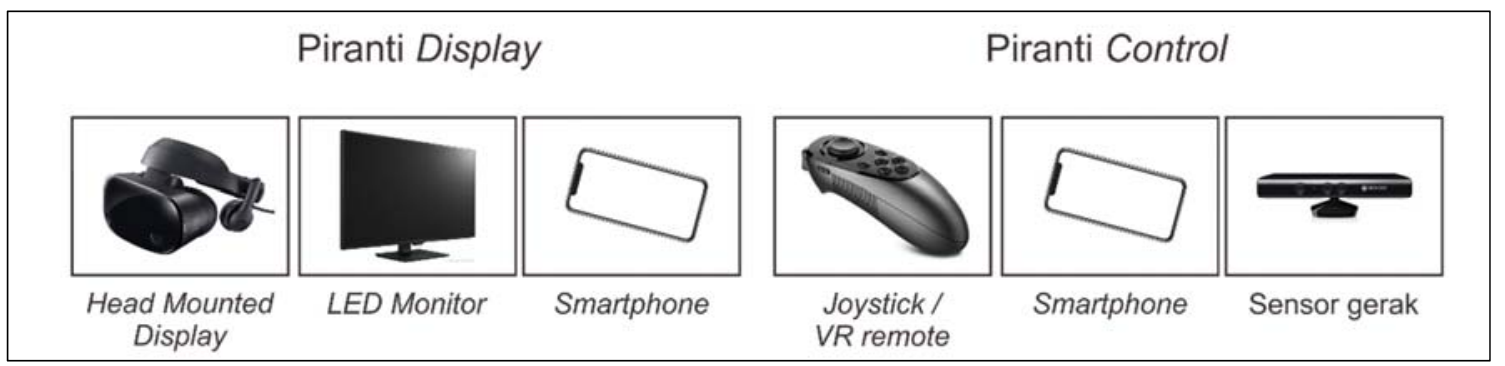

Gambar 4. Contoh Perangkat Keras Virtual Reality (VR)

Sumber: Dokumentasi Penulis (2019) 


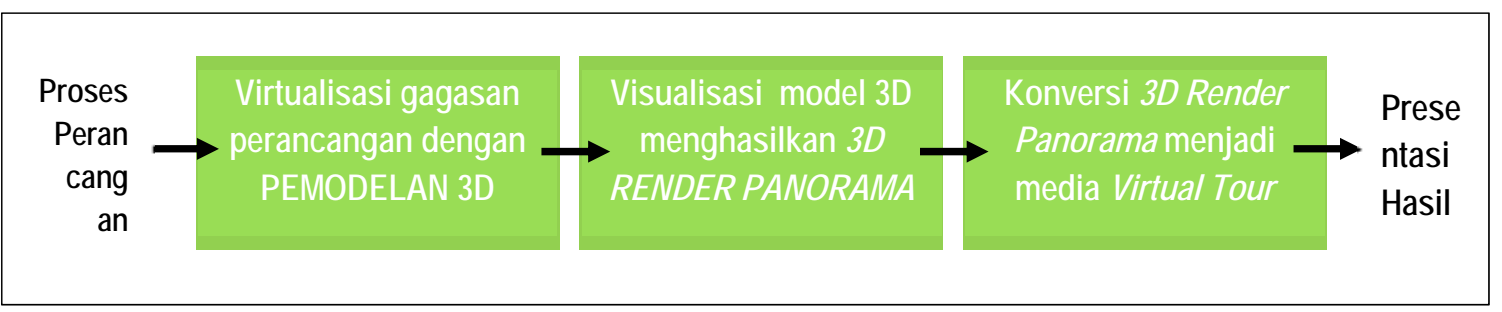

Gambar 5. Bagan Alir Kerja Pembuatan Media Presentasi Perancangan Interior berbasis Virtual Tour Sumber: Dokumentasi Penulis (2019)

\section{Perangkat Lunak Pendukung Pembuatan Virtual Tour}

Dalam rangkaian kerja sesuai bagan di gambar 5, berikut penjelasan mengenai perangkat lunak yang digunakan pada masing-masing tahapan utama:

\section{Program Pemodelan 3D Sketchup}

Program komputer Sketchup pertama kali dikembangkan oleh Google dan selanjutkan dikembangkan oleh Trimble mulai versi tahun 2013 pada versi yang terkini. Sketchup banyak digunakan sebagai pemodelan 3D pada bidang arsitektur, desain interior, arsitektur lanskap, teknik sipil, teknik mesin, perfilman dan video game (Setiawan, 2011). Sketchup memiliki beberapa kelebihan sebagai berikut:

- Memiliki workflow dan user interface yang Intuitif, mudah digunakan, dan memiliki versi gratis tanpa harus membeli lisensi.

- Dapat mendapatkan file-file 3D yang memiliki kompabilitas file dengan Sketchup secara gratis pada web 3 WWarehouse.

- Berbasis komunitas sehingga banyak konten-konten pelatihan maupun diskusi dapat diakses secara online di forum-forum pengguna Sketchup.

\section{Program Visualisai 3D Vray}

Vray adalah program komputer yang memvisualkan/rendering hasil pemodelan 3D. Pertama kali dikembangkan tahun 1997 oleh perusahaan asal Bulgaria, CHAOS group. VRay bekerja menggunakan teknik algoritma global illumination dimana jalur cahaya, pemetaan foton, peta radiasi dan iluminasi global dikalkulasikan untuk menghasilkan visualisasi. Penggunaan teknik ini sering membuatnya lebih baik dibandingkan cara-cara render yang digunakan oleh render engine lainnya. Umumnya proses render menggunakan teknik ini dapat menghasilkan gambar yang lebih realistis, walaupun sebenarnya hal tersebut merupakan efek pencahayaan virtual / tiruan (Nugraha, 2016). Vray termasuk program dengan format plugin dan dapat diintegrasikan ke banyak program pemodelan 3D seperti 3DSMax, Maya, Blender, Revit, Rhinoceros dan lain sebagainya.

\section{Program Komputer Penyusun Virtual Tour Pano2VR}

Program komputer Pano2VR dikembangkan oleh perusahaan teknologi informasi Garden Gnome, berjalan pada sistem operasi Windows maupun Mac. Fungsi utama Pano2VR adalah mengkoversi gambar panorama menjadi format Virtual Tour secara instan selanjutnya dimplementasikan menjadi tampilan interaktif berbasis Flash Multimedia. Selain dikonversi menjadi format interaktif, Virtual Tour hasil Pano2VR ditambahkan juga user interface untuk melakukan kontrol dan navigasi. Hasil Virtual Tour dapat ditampilkan dalam format HTML sehingga dengan mudah diunggah pada sistem berbasis web dan disajikan secara daring ataupun 
Okta P. S. Ardianto, Thomas A. Kristianto, Caesario A. Budianto, Anggra A. Rucitra, Adi Wardoyo Evaluasi Media Presentasi Perancangan Interior Rumah Air Surabaya Berbasis Virtual Tour sebagai Usaha Penerapan Building Information Modelling pada Perancangan Interior

dipresentasikan secara luring pada perangkat keras lokal. Tampilan interface perangkat lunak ini dapat diperhatikan pada gambar 6.

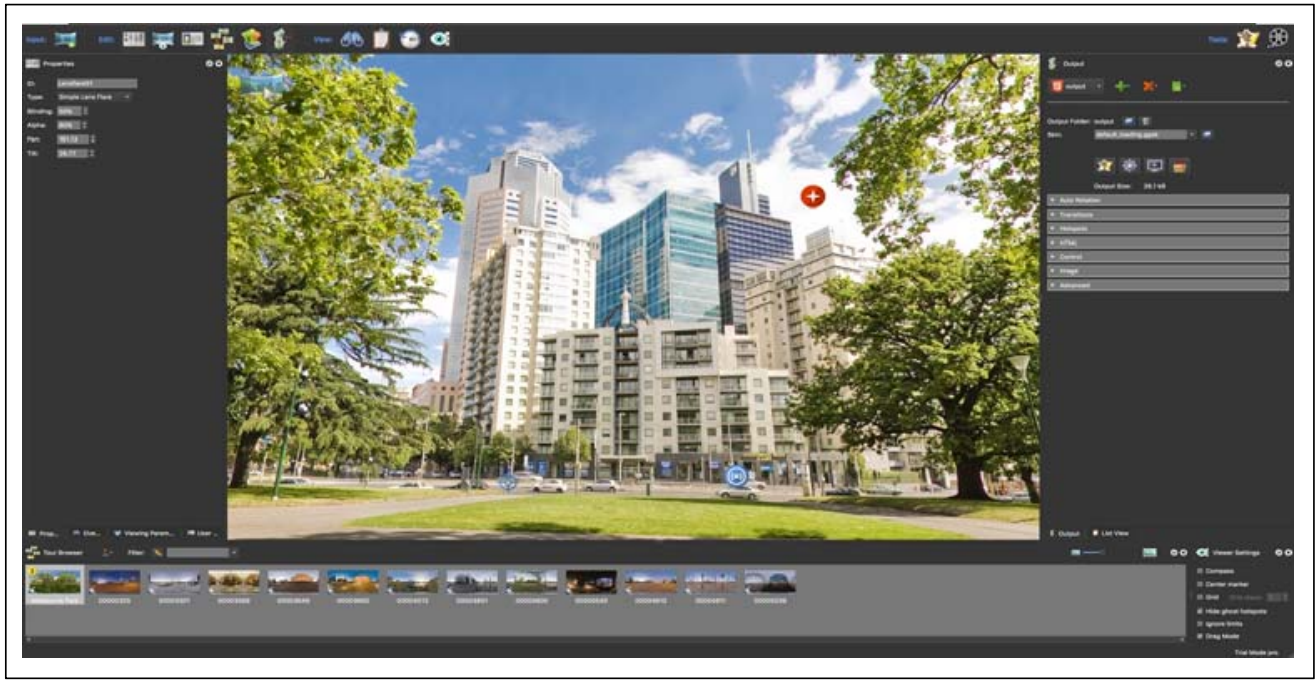

Gambar 6. Tampilan Interface Aplikasi Pano2VR

Sumber: Dokumentasi Penulis (2019)

\section{METODE PENELITIAN}

Secara umum, studi evaluasi ini menggunakan metode inspeksi pada media hasil perancangan interior berbasis virtual tour terpilih dengan rangkaian analisa, yaitu analisa deskriptif, heuristik dan kualitatif berdasarkan pada studi literatur BIM (Gambar 7). Media terpilih yang digunakan adalah media virtual tour data yang dimiliki dan merupakan hasil perancangan tim yang tergabung pada laboratorium Sains dan Teknologi Interior Departemen Desain Interior ITS yaitu media virtual tour dari perancangan interior Rumah Air PDAM Surya Sembada Surabaya. Analisa deskriptif sebagai analisa pertama dilakukan untuk mengetahui secara umum spesifikasi dan fitur masing-masing sampel agar memberikan pengetahuan awal sehingga dapat membantu analisa selanjutnya.

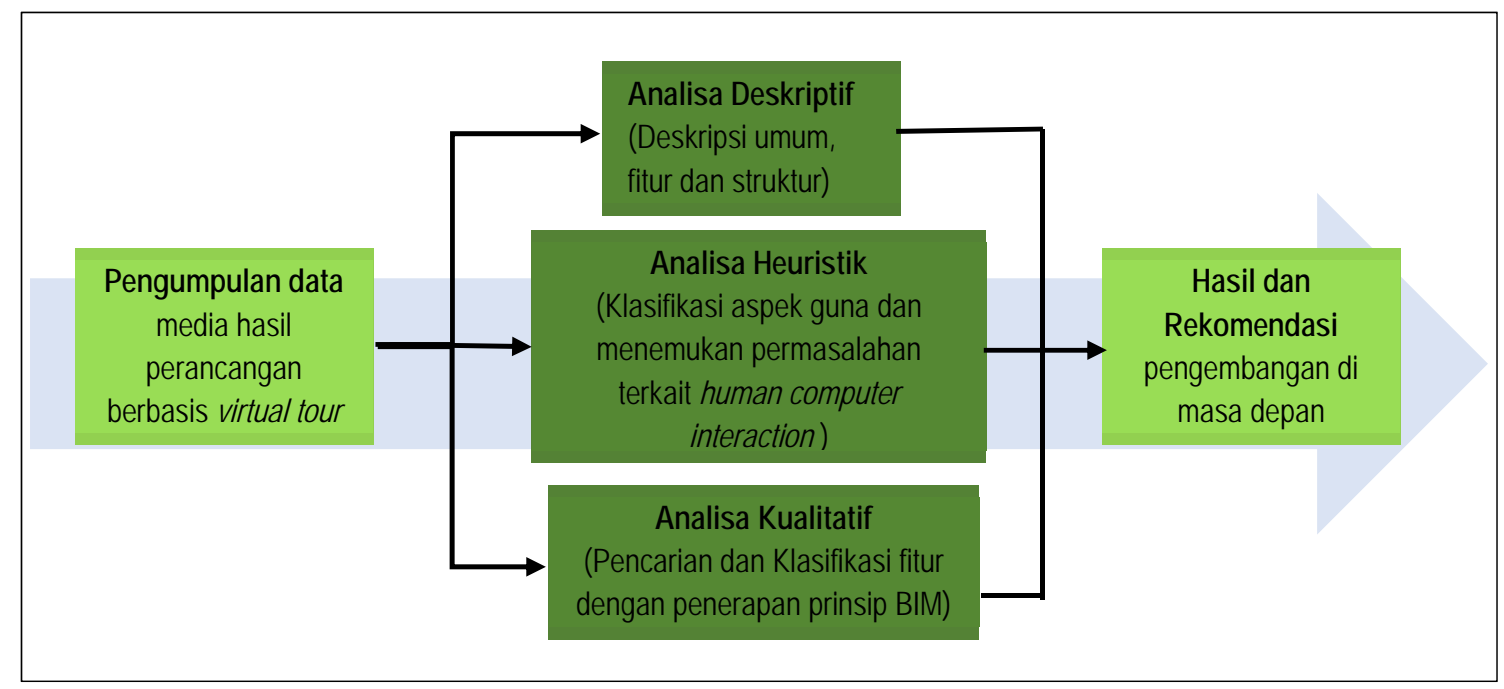

Gambar 7. Bagan Metode Penelitian

Sumber: Dokumentasi Penulis (2019) 
Virtual Tour sebagai media baru seperti VR memberikan pengalaman interaksi manusia dan komputer (Human Computer Interaction / HCI) yang berbeda dibanding media virtual lain karena terdapat aspek interaktif. Oleh karena dilakukan analisa kedua yaitu analisa heuristik dikarenakan analisa tersebut merupakan salah satu metode dengan pendekatan eksploratif untuk mencari aspek guna dan kelemahan suatu sistem keteknikan media HCI. Selain itu, metode ini mempunyai kelebihan dapat dilakukan dengan cepat, berbiaya hemat dan mampu menangkap banyak persoalan terkait usabilitas sebuah media HCI (Nielsen, 1993). Analisa ini dilakukan oleh 3 pengamat dari tim penulis dengan 3 tahapan. Tahapan pertama adalah audit teknologi, pemetaan masalah desain interaksi virtual tour dan pengguna menggunakan 12 aspek heuristik dan pemeringkatan skala permasalahan serta usulan solusi. Teknik yang digunakan merupakan rumusan Sutcliffe (2004) yang digunakan untuk mengevaluasi media VR. Analisa ketiga yaitu analisa kualitatif dengan cara memperhatikan temuan pada analisa sebelumnya lalu dibandingkan dengan aspek BIM yang didapat dari hasil studi literatur. Diharapkan dari analisa ini didapat temuan korelasi antara aspek media hasil perancangan interior berbasis virtual tour dengan penerapan prinsip BIM.

\section{HASIL PENELITIAN DAN PEMBAHASAN}

\section{A. Deskripsi dan Desain Virtual Tour Rumah Air Surabaya}

Rumah Air Surabaya adalah fasilitas galeri dan edukasi tentang sumber daya air bersih milih PDAM Surya Sembada Surabaya yang dapat dikunjungi oleh masyarakat dengan sistem kunjungan menggunakan reservasi terbatas. Fasilitas ini berada di salah satu komplek aset milik PDAM Surya Sembada Surabaya di Jalan Basuki Rahmat 119-121 Surabaya. Peracangan interior dilakukan pada pertengahan tahun 2015 dan saat ini telah dilakukan pelaksanaan tahap pertama sebagai sebagian dari hasil perancangan. Sebagai bagian dari tahapan perancangan, tim perancang menggunakan media presentasi berbasis virtual tour. Teknis mengenai alir kerja pembuatan media tersebut telah dijelaskan pada bab sebelumnya dan dapat dengan dipelajari dengan singkat dengan memperhatikan gambar 5. Sementara informasi umum mengenai file media presentasi dapat diperhatikan pada tabel 3.

Tabel 3. Informasi Umum Media Presentasi Presentasi Perancangan Interior Rumah Air Surabaya Berbasis

\begin{tabular}{|l|l|l|}
\hline \multicolumn{1}{|c|}{ Aspek } & \multicolumn{1}{|c|}{ Parameter } & \multicolumn{1}{c|}{ Keterangan } \\
\hline Ekstensi File & .html versi 5 & $\begin{array}{l}\text { Dapat dibuka di perangkat komputasi saat ini } \\
\text { (PC, gawai maupun posel cerdas })\end{array}$ \\
\hline Input Kontrol & Sesuai perangkat & Dapat dengan mouse, joystick atau layer sentuh \\
\hline Konsep Render & Static Rendering & $\begin{array}{l}\text { Ringan sehingga tidak membutuhkan } \\
\text { kemampuan perangkat yang tinggi }\end{array}$ \\
\hline
\end{tabular}

Sumber: Dokumentasi Penulis (2019)

Media presentasi perancangan interior Rumah Air Surabaya berbasis virtual tour secara umum menampilkan hasil perancangan berupa gambar desain 3D render yang merepresentasikan warna, konfigurasi elemen interior dan simulasi pencahayaan yang interaktif. Fitur interaktif di sini meliputi beberapa poin yaitu, arah pandangan (view) dapat dirubah sesuai keinginan, lokasi ruang dapat berpindah ke beberapa titik di dalam area terdesain (teleport) dan terdapat popup information di tampilan presentasi yang menampilkan informasi 
Okta P. S. Ardianto, Thomas A. Kristianto, Caesario A. Budianto, Anggra A. Rucitra, Adi Wardoyo Evaluasi Media Presentasi Perancangan Interior Rumah Air Surabaya Berbasis Virtual Tour sebagai Usaha Penerapan Building Information Modelling pada Perancangan Interior

tambahan. Keseluruhan fitur tersebut dapat disajikan dan dikendalikan oleh penyaji ketika menjelaskan desain kepada klien atau masyarakat. Titik lokasi yang dapat diakses berada di masing-masing ruangan di dalam area Rumah Air Surabaya. Total terdapat 7 titik tersebar mulai dari lobby hingga pada chapter-chapter tematik, lokasi titik teleport terhadap area Rumah Air Surabaya dapat diperhatikan pada gambar 8.

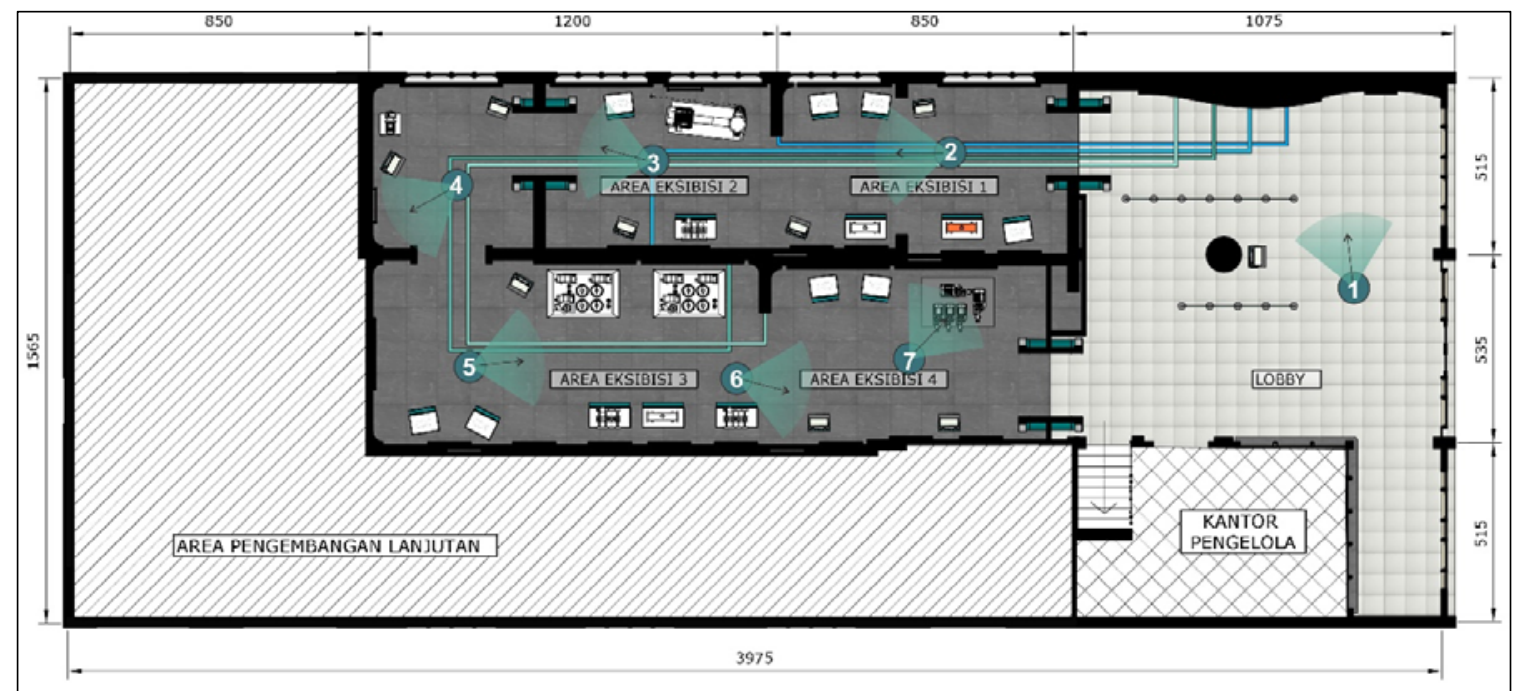

Gambar 8. Persebaran Titik Teleport di Area Rumah Air Surabaya

Sumber: Dokumentasi Penulis (2019)

Persebaran titik teleport yang ada telah mencakup keseluruhan ruang terdesain yang akan ditampilkan ketika presentasi desain. Dengan pola tersebut maka penyaji dapat berpindah titik lalu menjelaskan masing-masing hasil desain di tiap ruang sehingga hasil perancangan interior seluruh ruang dapat disampaikan dengan optimal, yaitu dengan menjelaskan penerapan desain dengan menavigasi media presentasi secara interaktif melalui perubahan pandangan di masingmasing ruang sehingga tampilan keseluruhan ruang dapat disajikan dengan komprehensif. Selain itu di lokasi tertentu terdapat fitur menampilkan popup information yang memberi penjelasan lebih detail mengenai poin yang penting atau perlu penekanan, tampilan ketika muncul popup information dapat diperhatikan pada gambar 9. Lebih detail mengenai konfigurasi dan tampilan media presentasi dapat diperhatikan pada tabel 3 berikut ini: 
Tabel 3. Informasi Detail Media Presentasi Presentasi Perancangan Interior Rumah Air Surabaya Berbasis Virtual Tour

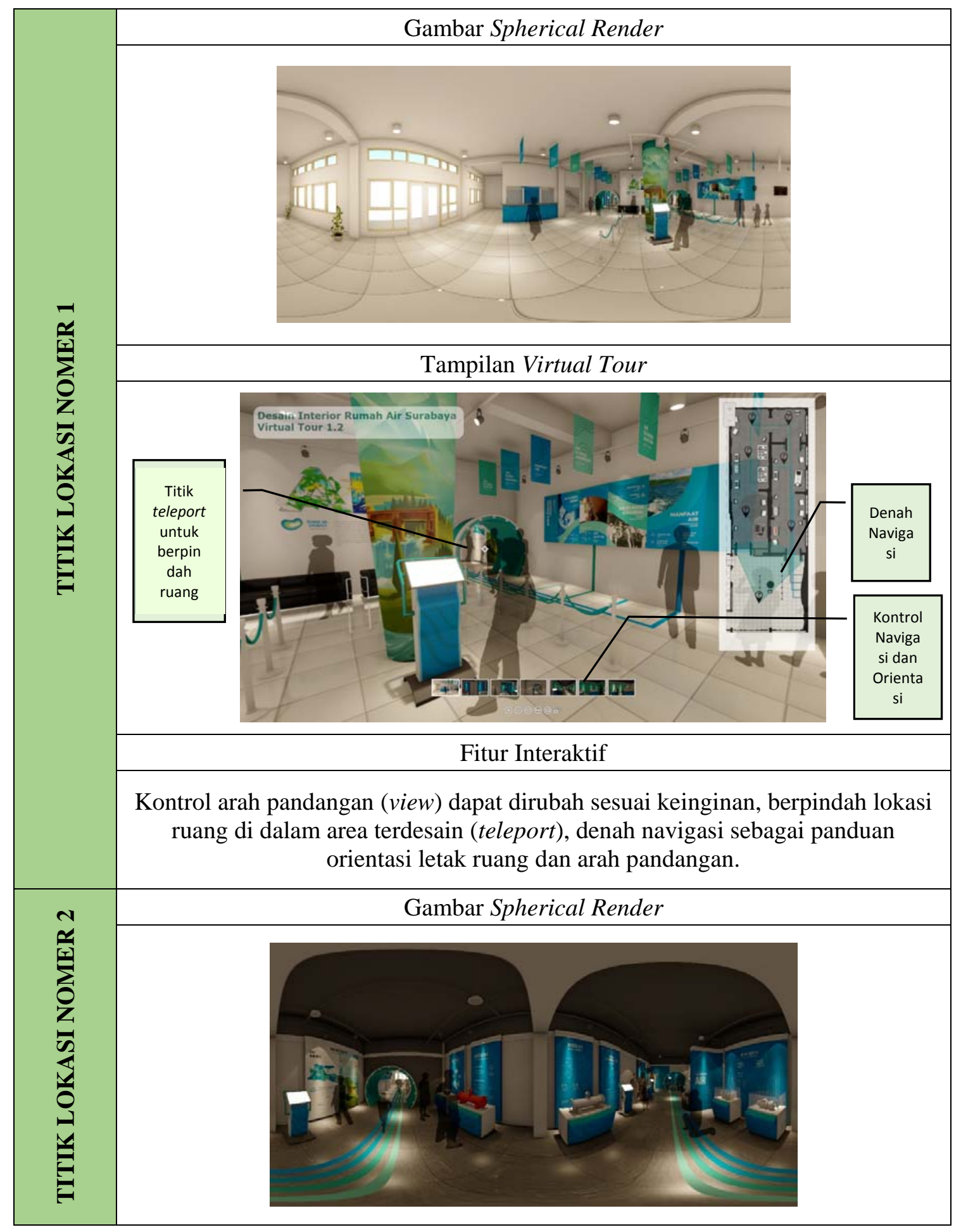


Okta P. S. Ardianto, Thomas A. Kristianto, Caesario A. Budianto, Anggra A. Rucitra, Adi Wardoyo Evaluasi Media Presentasi Perancangan Interior Rumah Air Surabaya Berbasis Virtual Tour sebagai Usaha Penerapan Building Information Modelling pada Perancangan Interior

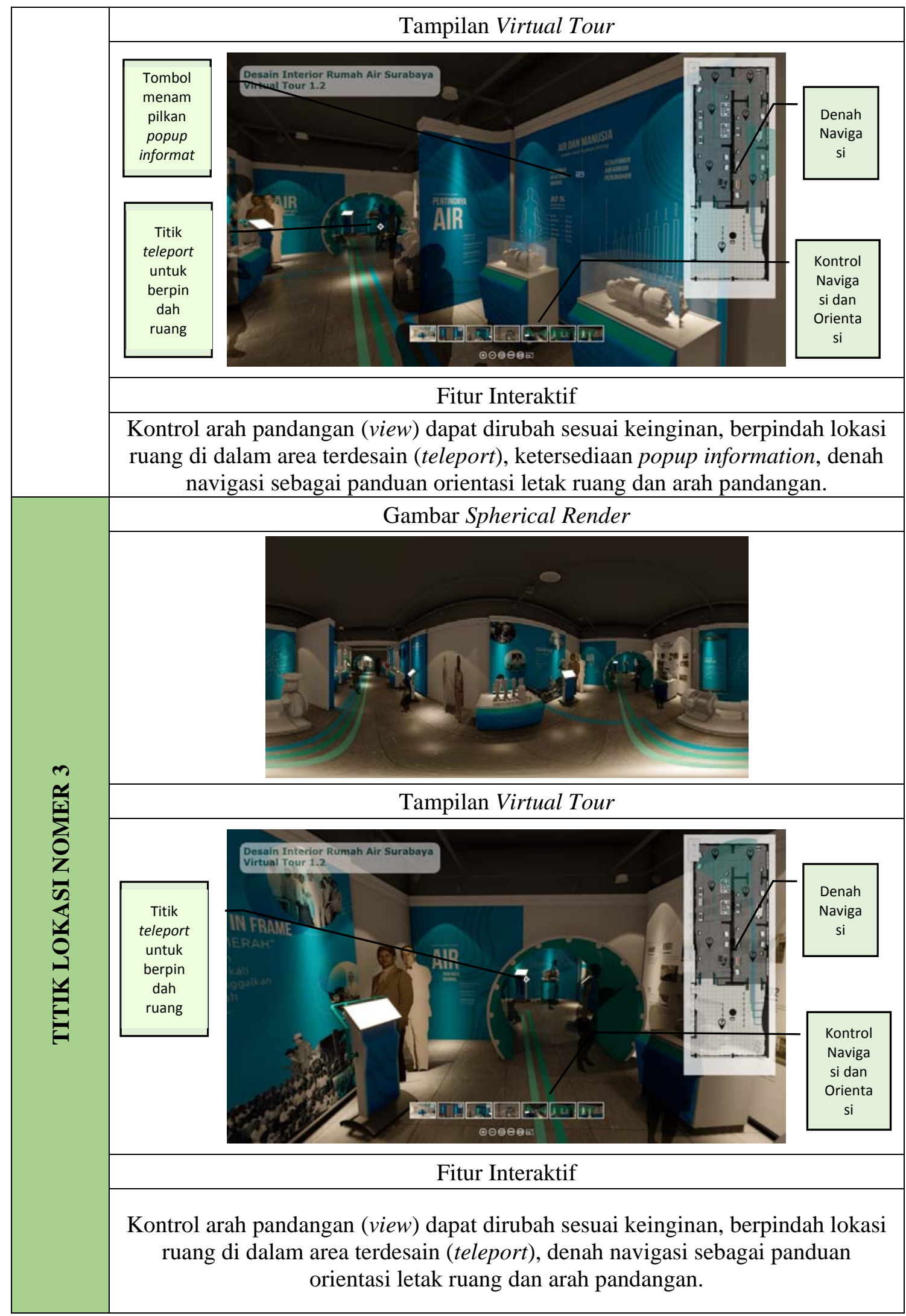




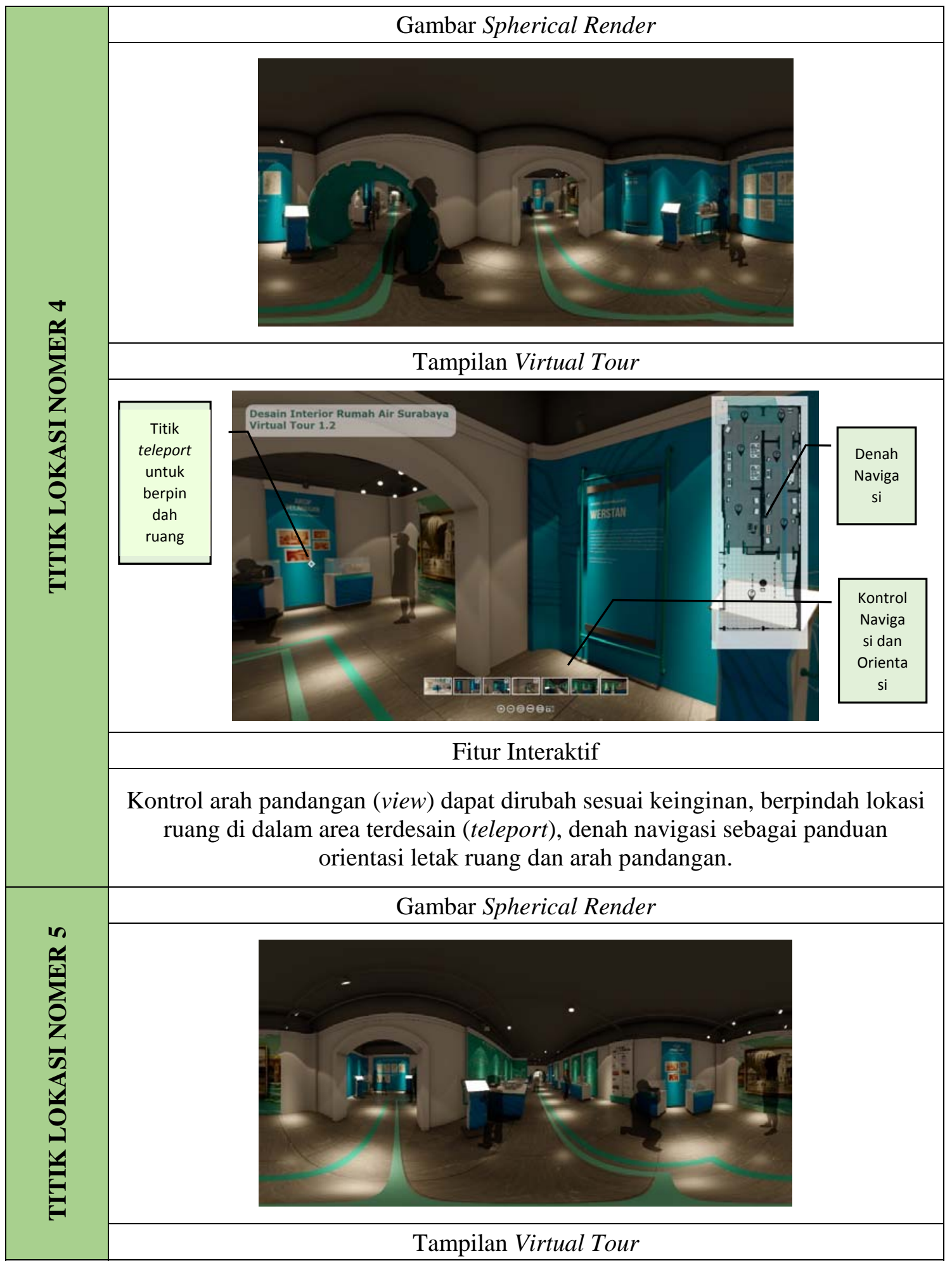


Okta P. S. Ardianto, Thomas A. Kristianto, Caesario A. Budianto, Anggra A. Rucitra, Adi Wardoyo Evaluasi Media Presentasi Perancangan Interior Rumah Air Surabaya Berbasis Virtual Tour sebagai Usaha Penerapan Building Information Modelling pada Perancangan Interior

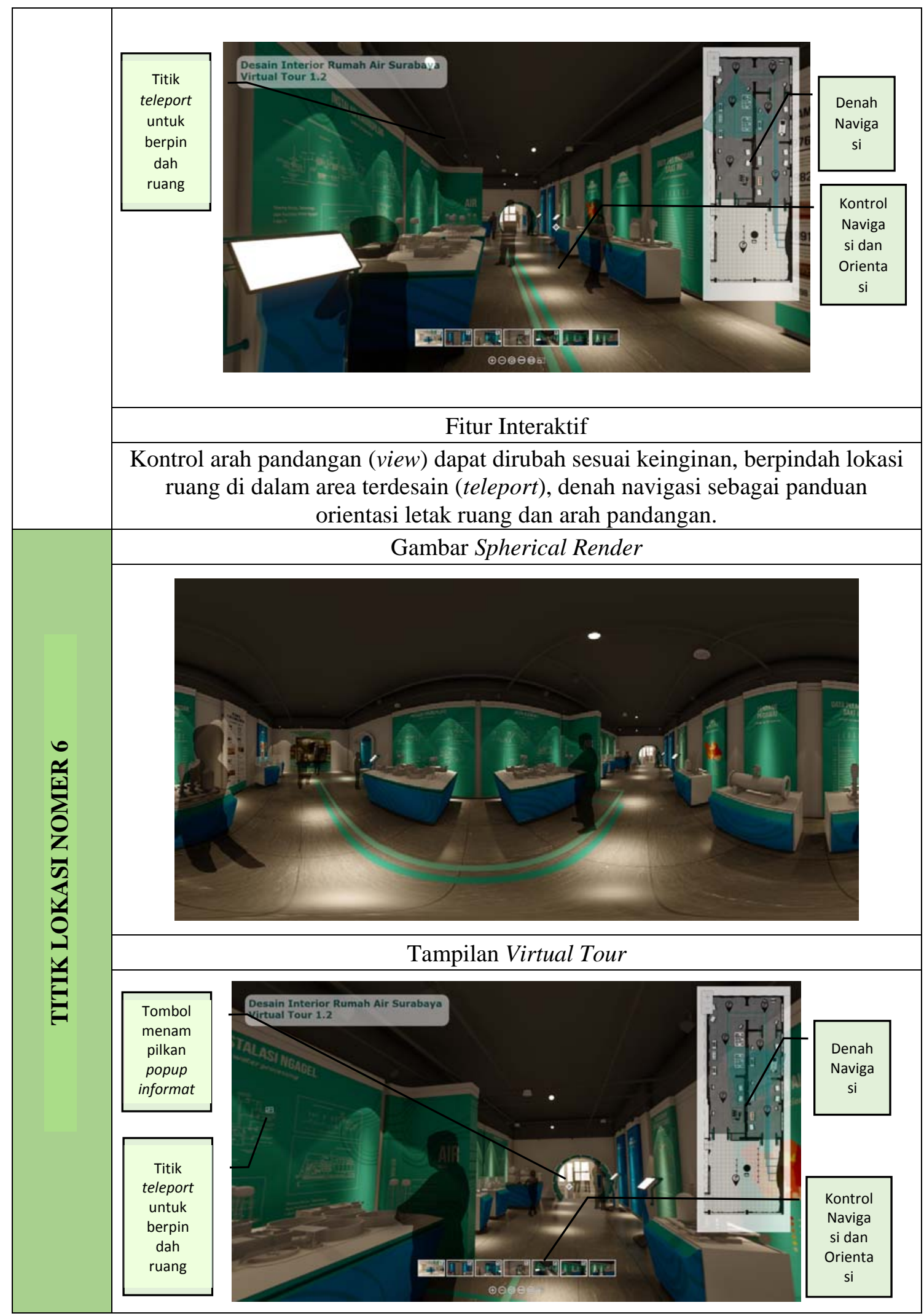




\section{Di|Fin}

Vol. 4, No. 1, Juni 2019, pISSN 2527-2853, eISSN 2549-2985

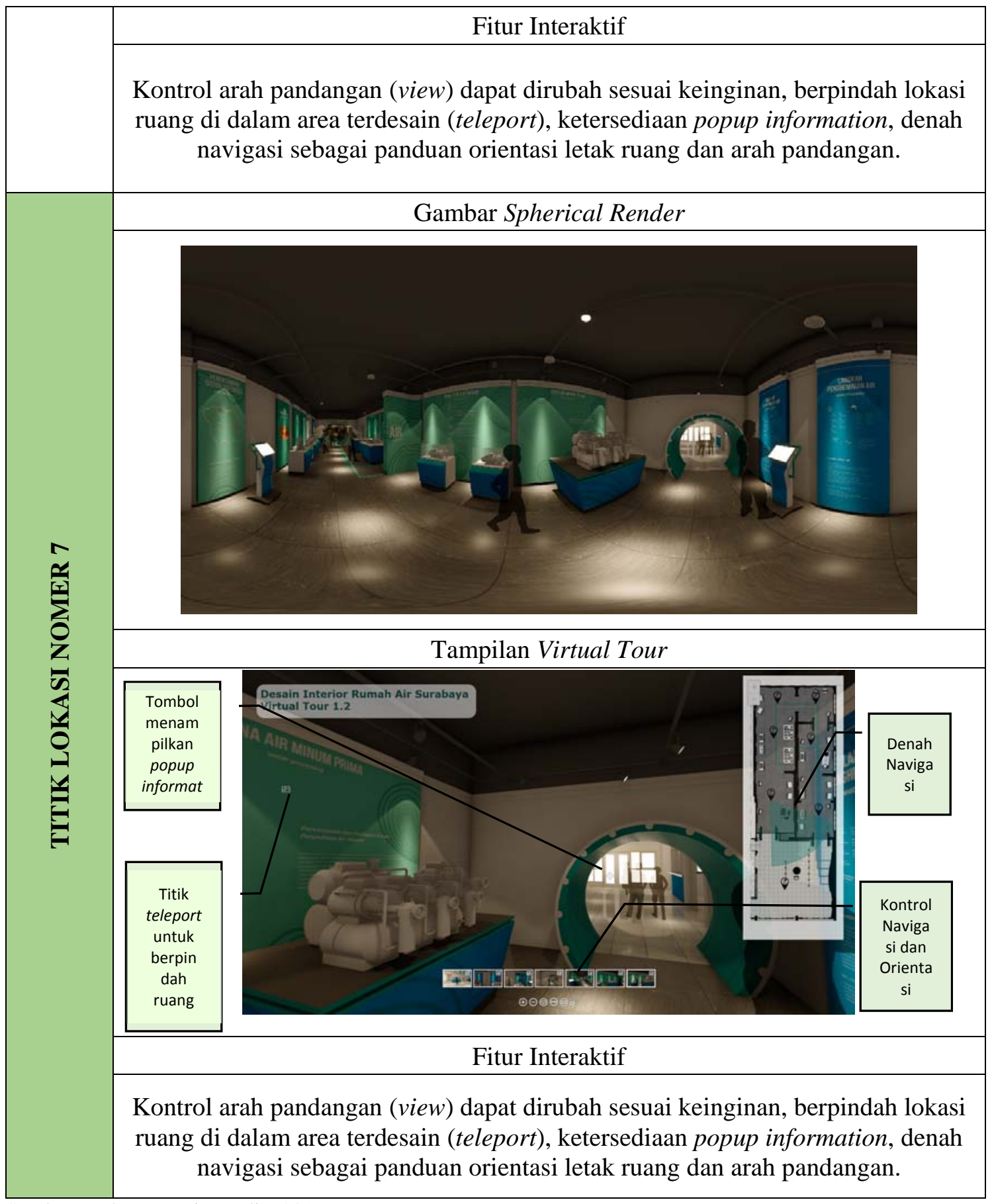

Sumber: Dokumentasi Penulis (2019) 
Okta P. S. Ardianto, Thomas A. Kristianto, Caesario A. Budianto, Anggra A. Rucitra, Adi Wardoyo Evaluasi Media Presentasi Perancangan Interior Rumah Air Surabaya Berbasis Virtual Tour sebagai Usaha Penerapan Building Information Modelling pada Perancangan Interior

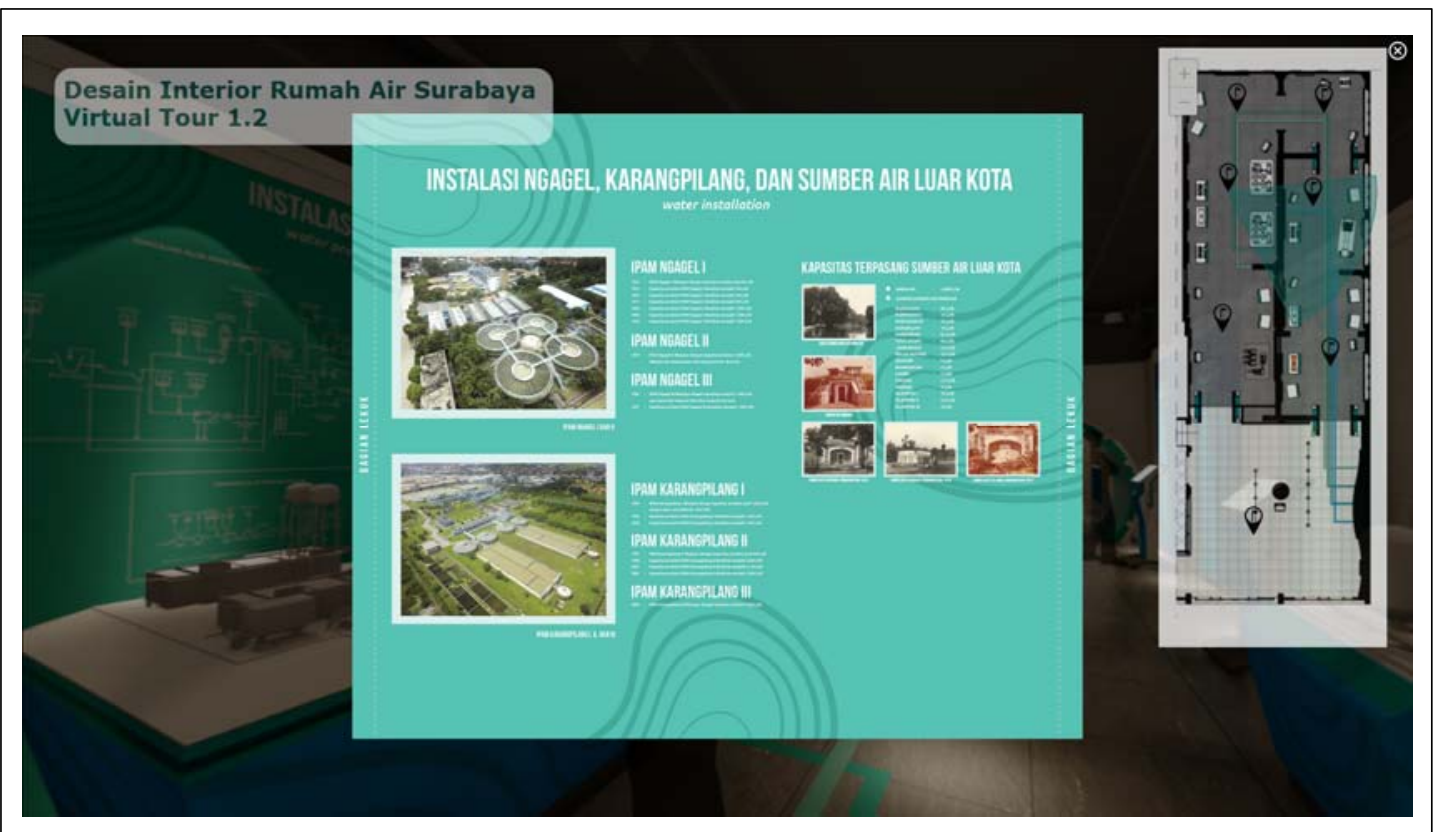

Gambar 9. Contoh Tampilan Popup Information pada Media Presentasi Presentasi Perancangan Interior Rumah Air Surabaya Berbasis Virtual Tour Sumber: Dokumentasi Penulis (2019)

\section{B. Analisa Heuristik Virtual Tour Rumah Air Surabaya}

Pada bagian sebelumnya telah dilakukan analisa deskriptif mengenai media presentasi Perancangan Interior Rumah Air Surabaya berbasi virtual tour sehingga telah diketahui poinpoin dasar mengenai media presentasi tersebut. Pada bagian ini dilakukan analisa dengan pendekatan heuristik sebagai bagian dari rangkaian studi untuk mengetahui tingkat kenyamanan antar muka bagi penyaji maupun bagi klien yang mengikuti presentasi. Tahapan analisa seperti yang dijelaskan pada bagian metode penelitian dilakukan dan memberikan hasil sebagai berikut:

\section{Audit Teknologi}

Tahapan paling awal dari analisa adalah audit teknologi untuk memberikan gambaran dan pengenalan dasar kepada peneliti agar dapat melakukan analisa di tahapan berikutnya dengan lebih optimal, audit teknologi menggunakan aspek sesuai Sutcliffe (2004) dengan hasil sebagai berikut:

Operation of the user's presence: Virtual tour berbeda dengan virtual reality dalam menyajikan realitas buatan, yaitu tidak sepenuhnya memisahkan penyaji dengan realitas nyata sepenuhnya sehingga pada aspek ini keberadaan penyaji dapat diwakili dengan kursor di layar sebagai panduan arah pandangan serta sebagai cursor kendali untuk mengaktifkan menu-menu interaktif pada media presentasi.

Haptic feedback: Media presentasi memberikan umpan balik secara visual, salah satu contohnya adalah ketika cursor diarahkan melewati titik-titik teleport pada menu peta navigasi maka akan memunculkan informasi nama ruang tempat keberadaan titik teleport tersebut.

Interactive techniques: Seperti yang telah dijelaskan pada bagian sebelumnya terdapat fitur interaktif utama yaitu arah pandangan (view) dapat dirubah sesuai keinginan, lokasi ruang dapat berpindah ke beberapa titik di dalam area terdesain (teleport) dan terdapat popup information di tampilan presentasi yang menampilkan informasi tambahan. 
Realistic graphics: Media virtual tour tersusun dari gambar render photorealistic sehingga kualitas material, dimensional, warna hingga pencahayaan dapat direpresentasikan dengan optimal.

2. Pemetaan Masalah dengan Prinsip Heuristik

Setelah mengenali poin dasar pada tahapan audit teknologi dilakukan pemetaan permasalahan yang muncul menggunakan panduan 12 prinsip heuristik dan menentukan peringkat kepentingannya. Hasil pemetaan tersebut dapat diperhatikan pada tabel 4 sebagai berikut:

Tabel 4. Pemetaan Masalah dengan Prinsip Heuristik Media Presentasi Presentasi Perancangan Interior Rumah Air Surabaya Berbasis Virtual Tour

\begin{tabular}{|c|c|c|c|}
\hline No & Prinsip Heuristik & Peringkat & Permasalahan yang Muncul \\
\hline 1 & Natural engagement & 2 & $\begin{array}{l}\text { Perpindahan lokasi hanya terbatas pada titik } \\
\text { teleport yang telah disediakan dan tidak } \\
\text { bisa berpindah dengan sangat bebas } \\
\text { (walkthrough) } \\
\text { - Realitas buatan yang ditampilkan tidak } \\
\text { memisahkan penyaji dengan realitas nyata. }\end{array}$ \\
\hline 2 & $\begin{array}{l}\text { Compatibility with the } \\
\text { user's task and } \\
\text { domain }\end{array}$ & N/A & Tidak ditemukan masalah berarti \\
\hline 3 & $\begin{array}{l}\text { Natural expression of } \\
\text { action }\end{array}$ & 3 & $\begin{array}{l}\text { - Tidak tersedia fitur interaktif berupa } \\
\text { interaksi dengan benda interior, semisal } \\
\text { memindah lokasi furnitur. } \\
\text { - Perpindahan antar titik teleport memiliki } \\
\text { efek transisi yang tidak alami }\end{array}$ \\
\hline 4 & $\begin{array}{l}\text { Close coordination of } \\
\text { action and } \\
\text { representation }\end{array}$ & 1 & $\begin{array}{l}\text { - Tampilan teks keterangan di beberapa } \\
\text { bagian seperti contohnya di label } \\
\text { keterangan titik teleport terlihat kurang } \\
\text { halus dan proporsi. } \\
\text { - Pada saat dilakukan perubahan pandangan } \\
\text { dengan gerakan cepat terdapat efek distorsi } \\
\text { pada tampilan yang terasa cukup } \\
\text { mengganggu. }\end{array}$ \\
\hline 5 & Realistic feedback & N/A & Tidak ditemukan masalah berarti \\
\hline 6 & Faithful viewpoints & N/A & Tidak ditemukan masalah berarti \\
\hline 7 & $\begin{array}{l}\text { Navigation and } \\
\text { orientation support }\end{array}$ & N/A & $\begin{array}{l}\text { Tidak ditemukan masalah berarti, navigasi } \\
\text { banyak terbantu dengan tombol kontrol dan } \\
\text { orientasi terbantu dengan denah navigasi }\end{array}$ \\
\hline
\end{tabular}


Okta P. S. Ardianto, Thomas A. Kristianto, Caesario A. Budianto, Anggra A. Rucitra, Adi Wardoyo Evaluasi Media Presentasi Perancangan Interior Rumah Air Surabaya Berbasis Virtual Tour sebagai Usaha Penerapan Building Information Modelling pada Perancangan Interior

\begin{tabular}{|c|c|c|c|}
\hline No & Prinsip Heuristik & Peringkat & Permasalahan yang Muncul \\
\hline 8 & $\begin{array}{l}\text { Clear entry and exit } \\
\text { points }\end{array}$ & N/A & $\begin{array}{l}\text { Tidak ditemukan masalah berarti, menampilkan } \\
\text { layar menjadi fullscreen dapat dilakukan } \\
\text { dengan tombol navigasi yang tersedia. }\end{array}$ \\
\hline 9 & $\begin{array}{l}\text { Consistent } \\
\text { departures }\end{array}$ & 4 & $\begin{array}{l}\text { Tombol trigger pada fitur interaktif seperti } \\
\text { titik teleport dan memunculkan popup } \\
\text { information memiliki ukuran yang terlalu kecil. }\end{array}$ \\
\hline 10 & Support for learning & 5 & Belum terdapat panduan penggunaan di layar \\
\hline 11 & Clear turn-taking & N/A & Tidak ditemukan masalah berarti \\
\hline 12 & Sense of presence & 6 & $\begin{array}{l}\text { Tidak adanya penanda kehadiran secara virtual } \\
\text { seperti tangan virtual, digantikan dengan } \\
\text { tampilan cursor. }\end{array}$ \\
\hline
\end{tabular}

Sumber: Dokumentasi Penulis (2019)

\section{Klasifikasi Masalah dan Usulan Solusi}

Dari tahapan pemetaan masalah dengan prinsip heuristik telah diketahui permsalahan yang secara umum disebabkan karena keterbatasan fitur interaktif dan gangguan tampilan. Selanjutnya pada tahapan ini dilakukan klasifikasi masalah dengan mengelompokkan pada poin-poin permasalahan dan mengukur tingkat keparahan gangguan disertai usulan solusi yang dapat menyelesaikan permasalahan. Lebih detail mengenai tahapan ini dapat diperhatikan pada tabel 5 berikut:

Tabel 5. Klasifikasi Permasalahan dan Usulan Solusi Media Presentasi Presentasi Perancangan Interior Rumah Air Surabaya Berbasis Virtual Tour

\begin{tabular}{|l|l|l|l|}
\hline $\begin{array}{c}\text { Klasifikasi } \\
\text { Permasalahan }\end{array}$ & \multicolumn{1}{|c|}{$\begin{array}{c}\text { Deskripsi } \\
\text { Permasalahan }\end{array}$} & $\begin{array}{c}\text { Tingkat } \\
\text { Keparahan }\end{array}$ & \multicolumn{1}{|c|}{ Usulan Solusi } \\
\hline Graphics & $\begin{array}{l}\text { - Kualitas dan } \\
\text { proporsi teks } \\
\text { kurang. } \\
\text { - Gejala distorsi } \\
\text { pada perubahan } \\
\text { arah pandangan }\end{array}$ & $\begin{array}{l}\text { Gangguan } \\
\text { sedang }\end{array}$ & $\begin{array}{l}\text { Melakukan } \\
\text { rekonfigurasi pada } \\
\text { pengeditan virtual tour } \\
\text { dan menggunakan 3D } \\
\text { render cubical dan } \\
\text { bukan spherical. }\end{array}$ \\
\hline Presence & $\begin{array}{l}\text { Penanda keberadaan } \\
\text { pada dunia virtual } \\
\text { kurang }\end{array}$ & $\begin{array}{l}\text { Gangguan } \\
\text { kecil }\end{array}$ & $\begin{array}{l}\text { Menambahkan fitur } \\
\text { crosshair }\end{array}$ \\
\hline
\end{tabular}




\begin{tabular}{|c|c|c|c|}
\hline $\begin{array}{c}\text { Klasifikasi } \\
\text { Permasalahan }\end{array}$ & $\begin{array}{c}\text { Deskripsi } \\
\text { Permasalahan }\end{array}$ & $\begin{array}{c}\text { Tingkat } \\
\text { Keparahan }\end{array}$ & Usulan Solusi \\
\hline Interaction & $\begin{array}{l}\text { - Keterbatasan } \\
\text { interaksi dengan } \\
\text { objek interior } \\
\text { terdesain } \\
\text { - Tidak ada menu } \\
\text { modifikasi objek } \\
\text { interior terdesain }\end{array}$ & $\begin{array}{l}\text { Gangguan } \\
\text { kecil }\end{array}$ & $\begin{array}{l}\text { Mempertimbangkan } \\
\text { menggunakan aplikasi } \\
\text { berbasis gam engine } \\
\text { agar interaksi lebih } \\
\text { bervariasi }\end{array}$ \\
\hline $\begin{array}{l}\text { Environmental } \\
\text { Feature }\end{array}$ & N/A & & \\
\hline Controls & $\begin{array}{l}\text { - Tombol titik } \\
\text { teleport terlalu } \\
\text { kecil } \\
\text { - Tombol shortcut } \\
\text { memunculkan } \\
\text { popup information } \\
\text { terlalu kecil }\end{array}$ & $\begin{array}{l}\text { Gangguan } \\
\text { sedang }\end{array}$ & $\begin{array}{l}\text { Melakukan } \\
\text { rekonfigurasi pada } \\
\text { pengeditan virtual tour } \\
\text { terutama pada bagian } \\
\text { skin virtual tour }\end{array}$ \\
\hline Hardware & $\begin{array}{l}\text { - Kendala pada } \\
\text { peralatan multi } \\
\text { resolusi } \\
\text { - Terjadi lag jika } \\
\text { menggunakan } \\
\text { standar } \\
\text { renderberesolusi } \\
\text { tinggi pada } \\
\text { perangkat keras } \\
\text { portable (Laptop, } \\
\text { ponsel cerdas) }\end{array}$ & $\begin{array}{l}\text { Gangguan } \\
\text { kecil }\end{array}$ & $\begin{array}{l}\text { Menyediakan perangkat } \\
\text { keras yang } \\
\text { berkemampuan grafis } \\
\text { cukup }\end{array}$ \\
\hline
\end{tabular}

Sumber: Dokumentasi Penulis (2019)

\section{Analisa Virtual Tour Rumah Air Surabaya dan Penerapan Building Information Modelling Perancangan Interior}

Pada tahapan ini dilakukan analisa kualitatif dengan cara memperhatikan temuan pada analisa sebelumnya lalu dibandingkan dengan aspek BIM yang didapat dari hasil studi literatu. Tahapan ini bertujuan agar diketahui sejauh mana media presentasi telah menerapkan prinsip BIM pada perancangan interior Rumah Air Surabaya. Dikarenakan penggunaan media presentasi ini pada tahapan perencanaan dan belum mencapai tahapan operasi bangunan maka dimensi BIM yang digunakan sebagai indikator analisa kualitatif tidak memasukkan BIM 7D. Analisa dapat diperhatikan pada tabel 6 sebagai berikut: 
Okta P. S. Ardianto, Thomas A. Kristianto, Caesario A. Budianto, Anggra A. Rucitra, Adi Wardoyo Evaluasi Media Presentasi Perancangan Interior Rumah Air Surabaya Berbasis Virtual Tour sebagai Usaha Penerapan Building Information Modelling pada Perancangan Interior

Tabel 6. Analisa Aspek Penerapan BIM pada Media Presentasi Perancangan Interior Rumah Air Surabaya Berbasis Virtual Tour

\begin{tabular}{|c|c|c|c|}
\hline $\begin{array}{l}\text { Dimensi } \\
\text { BIM }\end{array}$ & Parameter & $\begin{array}{c}\text { Status } \\
\text { Penerapan* }\end{array}$ & Keterangan Penerapan \\
\hline \multirow{6}{*}{ คి } & Laser Scanning & $T$ & $\begin{array}{l}\text { Tidak ada penerapan pada aspek } \\
\text { ini karena pengukuran dan } \\
\text { pengamblan data eksisting } \\
\text { perencaan dilakukan secara } \\
\text { manual walaupun terdapat } \\
\text { penggunaan pengukuran dengan } \\
\text { peralatan pemindai laser }\end{array}$ \\
\hline & CAD Modelling & $D$ & $\begin{array}{l}\text { Keseluruhan proses virtualiasi } \\
\text { perancangan mulai tahapan } \\
\text { modelling, rendering hingga } \\
\text { pembuatan interaktif } \\
\text { menggunakan PC. }\end{array}$ \\
\hline & $\begin{array}{l}\text { Interactive } \\
\text { Visualization }\end{array}$ & $D$ & $\begin{array}{l}\text { Visualisasi dengan fitur interaktif } \\
\text { telah ada di media presentasi. } \\
\text { Contohnya fitur interaktif adalah } \\
\text { kontrol arah pandangan (view) } \\
\text { dapat dirubah sesuai keinginan, } \\
\text { berpindah lokasi ruang di dalam } \\
\text { area terdesain (teleport), } \\
\text { ketersediaan popup information, } \\
\text { denah navigasi sebagai panduan } \\
\text { orientasi letak ruang dan arah } \\
\text { pandangan. }\end{array}$ \\
\hline & Model Walkthrough & $D B$ & $\begin{array}{l}\text { Media presentasi dapat } \\
\text { melakukan walkthrough namun } \\
\text { belum pada tingkatan yang } \\
\text { leluasa karena titik-titik } \\
\text { pengamatan dibatasi dengan } \\
\text { jumlah titik teleport. Namun } \\
\text { persebaran titik teleport dapat } \\
\text { dibuat mewakili keseluruhan } \\
\text { ruang terdesain }\end{array}$ \\
\hline & Clash Detection & $T$ & $\begin{array}{l}\text { Tidak diterapkan karena } \\
\text { keterbatasan perangkat lunak } \\
\text { pembuat media presentasi. }\end{array}$ \\
\hline & $3 D$ Printing & $T$ & $\begin{array}{l}\text { Tidak diterapkan karena tidak } \\
\text { relevan dengan tujuan pembuatan } \\
\text { media presentasi }\end{array}$ \\
\hline
\end{tabular}




\begin{tabular}{|c|c|c|c|}
\hline $\begin{array}{c}\text { Dimensi } \\
\text { BIM }\end{array}$ & Parameter & $\begin{array}{c}\text { Status } \\
\text { Penerapan* }\end{array}$ & Keterangan Penerapan \\
\hline \multirow{6}{*}{ \& } & Project phasing simulation & $T$ & $\begin{array}{l}\text { Tidak diterapkan karena } \\
\text { keterbatasan perangkat lunak } \\
\text { pembuat media presentasi. }\end{array}$ \\
\hline & Project scheduling & $T$ & $\begin{array}{l}\text { Tidak diterapkan karena } \\
\text { keterbatasan perangkat lunak } \\
\text { pembuat media presentasi. }\end{array}$ \\
\hline & Plan of production & $T$ & $\begin{array}{l}\text { Tidak diterapkan karena } \\
\text { keterbatasan perangkat lunak } \\
\text { pembuat media presentasi. }\end{array}$ \\
\hline & Plan of take off & $T$ & $\begin{array}{l}\text { Tidak diterapkan karena } \\
\text { keterbatasan perangkat lunak } \\
\text { pembuat media presentasi. }\end{array}$ \\
\hline & Payment Scheduling & $T$ & $\begin{array}{l}\text { Tidak diterapkan karena } \\
\text { keterbatasan perangkat lunak } \\
\text { pembuat media presentasi. }\end{array}$ \\
\hline & Project phasing simulation & $T$ & $\begin{array}{l}\text { Tidak diterapkan karena } \\
\text { keterbatasan perangkat lunak } \\
\text { pembuat media presentasi. }\end{array}$ \\
\hline \multirow{3}{*}{ 응 } & $\begin{array}{l}\text { Quantity extraction support } \\
\text { to detailed budgeting }\end{array}$ & $T$ & $\begin{array}{l}\text { Tidak diterapkan karena } \\
\text { keterbatasan perangkat lunak } \\
\text { pembuat media presentasi. }\end{array}$ \\
\hline & Value analysis & $T$ & $\begin{array}{l}\text { Tidak diterapkan karena } \\
\text { keterbatasan perangkat lunak } \\
\text { pembuat media presentasi. }\end{array}$ \\
\hline & Multi-phase cost analysis & $T$ & $\begin{array}{l}\text { Tidak diterapkan karena } \\
\text { keterbatasan perangkat lunak } \\
\text { pembuat media presentasi. }\end{array}$ \\
\hline \multirow{3}{*}{ ดิ } & Energy analysis & $T$ & $\begin{array}{l}\text { Tidak diterapkan karena } \\
\text { keterbatasan perangkat lunak } \\
\text { pembuat media presentasi. }\end{array}$ \\
\hline & Sustainable element design & $T$ & $\begin{array}{l}\text { Tidak diterapkan karena } \\
\text { keterbatasan perangkat lunak } \\
\text { pembuat media presentasi. }\end{array}$ \\
\hline & $\begin{array}{l}\text { Environmental design } \\
\text { simulation }\end{array}$ & $D B$ & $\begin{array}{l}\text { Diterapkan sebagian terutama } \\
\text { pada visualisasi pencahayaan } \\
\text { alami lingkungan yang ada pada } \\
\text { area lobby. }\end{array}$ \\
\hline \multicolumn{4}{|c|}{$\begin{array}{l}\text { Keterangan: } \\
\mathrm{D} \quad \text { : Diterapkan } \\
\text { DS : Diterapkan sebagian } \\
\mathrm{T} \quad \text { : Tidak ada penerapan }\end{array}$} \\
\hline
\end{tabular}

Sumber: Dokumentasi Penulis (2019) 
Okta P. S. Ardianto, Thomas A. Kristianto, Caesario A. Budianto, Anggra A. Rucitra, Adi Wardoyo Evaluasi Media Presentasi Perancangan Interior Rumah Air Surabaya Berbasis Virtual Tour sebagai Usaha Penerapan Building Information Modelling pada Perancangan Interior

\section{KESIMPULAN}

Dari keseluruhan rangkaian analisa mengenai media presentasi Perancangan Interior Rumah Air Surabaya berbasis virtual tour didapat kesimpulan sebagai berikut:

- Visualisasi cukup optimal mendukung penjelasan hasil perancangan secara keseluruhan namun terdapat kendala pada fitur tampilan antar muka media presentasi diantaranya keterbatasan interaksi, dimensional tombol-tombol interaktif dan keberadaan distorsi yang cukup mengganggu secara visual.

- Penggunaan media presentasi berbasis virtual tour dapat dikategorikan sebagai penerapan BIM pada tahapan perencanaan desain interior namun terbatas pada dimensi BIM 3D yaitu penekanan pada virtualisasi dan komunikasi interaktif hasil perancangan.

- Sebagai media presentasi penekanan fungsi adalah visualisasi hasil perancangan dengan fitur interaktif untuk proses komunikasi desain dan belum pada integrasi dengan tahapan konstruksi maupun operasi bangunan (BIM 4D, 5D, 6D dan 7D).

Dengan memperhatikan kesimpulan tersebut sehingga dapat disusun saran penelitian yaitu sebagai berikut:

- Penggunaan media presentasi berbasi virtual tour relevan pada dukungan komunikasi hasil perancangan interior di era Industri 4.0 sehingga dapat digunakan sebagai media baru dalam komunikasi desain.

- Keterbatasan interaksi pada media presentasi dapat diatasi dengan penggunaan perangkat lunak berbasis game engine untuk pengembangan lebih lanjut. Namun terdapat potensi persoalan standar kemampuan perangkat keras, sehingga dapat dijadikan studi lanjutan.

\section{DAFTAR PUSTAKA}

Davies, R. (2015). Diambil kembali dari European Parliamentary Research Service: http://www.europarl.europa.eu/RegData/etudes/BRIE/2015/568337/EPRS_BRI(2015)5 68337_EN.pdf

Eastman, C., Teicholz, P., Sacks, R., \& Liston, K. (2008). BIM Handbook: A Guide to Building Information Modeling for Owners, Managers, Designers, Engineers, and Contractors. New Jersey: John Wiley \& Sons, Inc.

Kementrian Pekerjaan Umum dan Perumahan Rakyat. (2018). Kebijakan dan Roadmap Penerapan Building Information Modelling (BIM) Mendukung Konstruksi Digital Indonesia. Seminar Presentation. Jakarta, DKI Jakarta, Indonesia.

Nielsen, J. (1993). Usability Engineering. New York: Academic Press.

Nugraha, B. (2016). Perancangan Model 3D Datacenter Menggunakan Material dan Pencahayaan Vray. SEMNASTEKNOMEDIA ONLINE, Vol.4 No.1, 1-6.

Oesterreich, T., \& Teuteberg, T. (2016). Understanding the implications of digitisation and automation in the context of Industry 4.0: A triangulation approach and elements of a research agenda for the construction industry. Computers in Industry, 121-139.

Prasetyo, H., \& Sutopo, W. (2018). Industri 4.0: Telaah Klasifikasi Aspek dan Arah Perkembangan Riset. Jurnal Teknik Industri, Vol. 13 No. 1, 17-26.

Roh, S., Aziz, Z., \& Peña-Mora, F. (2011). An object-based 3D Walk-through Model for Interior Construction Progress Monitoring. Automation in Construction, 66-75.

Roussou, M. (2004). Learning by doing and learning through play: An exploration of interactivity in virtual environments for children. Computers in Entertainment, 1-23.

Setiawan, S. (2011). Google Sketchup Perangkat Alternatif dalam Pemodelan 3D. ULTIMATICS, Vol III No.2, 6-10.

Sutcliffe, A., \& Gault, B. (2004). Heuristic Evaluation of Virtual Reality Applications. Interacting with Computers, 16, 831-849. 